\author{
KATARZYNA JUREWICZ \\ Pracownia Neurobiologii Emocji \\ Instytut Biologii Doświadczalnej im. M. Nenckiego PAN \\ Pasteura 3, 02-093 Warszawa \\ E-mail: k.jurewicz@nencki.edu.pl
}

\title{
SIECI SPOCZYNKOWE I ICH ROLA W ZROZUMIENIU ORGANIZACJI FUNKCJONALNEJ MÓZGU*
}

\section{WSTEP}

Badanie aktywności spoczynkowej mózgu ma historię niewiele krótsza niż sama metoda funkcjonalnego obrazowania rezonansem magnetycznym (ang. functional magetic rezonans imaging, fMRI), której zaczęto używać w 1990 r. (OGAWA 1990). Funkcjonalny rezonans magnetyczny rejestruje zmiany natlenowania krwi, spowodowane zużyciem tlenu przez pobudzone komórki nerwowe, czyli sygnał BOLD (ang. blood-oxygenation level dependent). Metoda ta po raz pierwszy umożliwiła obserwowanie $z$ dużą precyzja $i$ w sposób całkowicie bezinwazyjny, jakie obszary mózgu angażuja się w trakcie dowolnych czynności poznawczych. Na poczatku lat 90. ubiegłego wieku na stanowisko doktoranta w Medical College of Wisconsin przyjęto Bharata Biswala, który miał badać własności sygnału BOLD. W szczególności, Biswal starał się opisać zależność między sygnałem BOLD $z$ kory ruchowej a poziomem aktywności neuronalnej. Aby to zrobić, musiał na początku poznać własności szumu obecnego w tym sygnale. Żeby uchwycić przewidywane, cykliczne źródła szumu, czyli aktywność związana $z$ praca serca, pulsem i oddychaniem, Biswal wykonał analize częstotliwościową sygnału BOLD zarejestrowanego podczas spontanicznej aktywności mózgu w obszarze kory ruchowej (BISwAL i współaut. 1995). Okazało się, że poza oscylacjami zwiazanymi $z$ biciem serca $(0,6-2$ $\mathrm{Hz})$ czy oddychaniem $(0,2-0,3 \mathrm{~Hz})$, istotna część sygnału stanowily fluktuacje znacznie (o rząd wielkości) od nich wolniejsze $(<0,08$ $\mathrm{Hz})$. Choć analizy częstotliwościowe wykonywane były na sygnale spoczynkowym, nagrywanym, gdy osoba leżąca $\mathrm{w}$ skanerze MRI nie była zajęta żadnym zadaniem, podobne, tj. zsynchronizowane, wolne fluktuacje występowały $\mathrm{w}$ dokładnie tych fragmentach kory czuciowo-ruchowej, które aktywowane były również przy wykonywaniu prostego zadania ruchowego (naprzemiennego poruszania palcami). Co było jeszcze bardziej zaskakujące, zsynchronizowana aktywność obejmowała nie tylko przylegajace do siebie obszary w jednej półkuli mózgu, ale również analogiczne obszary półkuli przeciwstronnej. Okazało się więc, że określone obwody neuronalne wykazuja zintegrowana aktywność nawet wtedy, gdy nie sa jawnie zaangażowane $\mathrm{w}$ procesy myślowe czy behawioralne. Wolne fluktuacje ujawniły ich spójność funkcjonalną, czyli wysoki poziom wewnętrznych powiazań, przewyższajacy synchronizacje $z$ innymi częściami mózgu. Obszary charakteryzujace się synchronicznymi, powolnymi zmianami aktywności nazwano więc sieciami spoczynkowymi (ang. resting state networks), samą zaś synchroniczną aktywność różnych, często odległych, regionów mózgu - połączeniem funkcjonalnym (ang. functional connectivity, FC).

Odkrycie Biswala przyniosło ze sobą ogromna liczbę pytań: czy poznano właśnie nowy system komunikacji w mózgu? Czy inne obszary wykazuja podobne relacje, a je-

Słowa kluczowe: fMRI, organizacja kory mózgu, połączenia funkcjonalne, sieci funkcjonalne, sieci połączeń wewnętrznych

*Praca powstała w wyniku realizacji projektów badawczych, finansowanych przez Narodowe Centrum Nauki (granty 2015/19/N/HS6/02364 i 2016/20/W/NZ4/00354). 
śli tak, to które? Jakie może być funkcjonalne znaczenie tego zjawiska? A może jednak jest to jakiegoś rodzaju artefakt? Jak ma się aktywność spoczynkowa do dynamicznie zachodzacych procesów poznawczych?

Autorzy doniesienia o wolnych fluktuacjach w korze ruchowej przeprowadzili jeszcze szereg badań, by udowodnić, że zaobserwowane synchronizacje nie sa "echem" po krótkotrwałej aktywności wywołanej dzialaniem, ani skutkiem pracy wyobraźni (np. wyobrażania sobie ruchów). Zmieniano parametry pomiaru i wstępnej rekonstrukcji sygnału fMRI, modyfikowano też szczegóły przebiegu badania, np. odtwarzając badanym muzykę, by przez zwrócenie uwagi na analizę bodźców słuchowych zmniejszyć prawdopodobieństwo aktywacji procesów w korze ruchowej (BISWAL 2012). Konkluzja pozostawała jedna taka sama: w różnych konfiguracjach badań i analiz nadal można było obserwować aktywność spoczynkowa odkrytej sieci.

Te poczatkowe ustalenia dały poczatek olbrzymiej gałęzi współczesnej neuronauki. Zajęła się ona nie tylko aktywnościa spoczynkowa, lecz ogólniej, próbą opisu architektury funkcjonalnej mózgu w terminach sieci połączeń. Obecnie, równie często jak o sieciach spoczynkowych, mówi się o sieciach połączeń wewnętrznych (ang. intrinsic connectivity networks, ICN), czy po prostu o sieciach funkcjonalnych, by objać jednocześnie różne aspekty aktywności sieciowej mózgu. Współcześnie wiadomo bowiem, że wspólny „szkielet” funkcjonalny leży u podłoża wszystkich stanów kognitywnych (przejawów aktywności mózgu), a wolne fluktuacje towarzysza dynamicznym zmianom aktywności neuronalnej (por. rozdz. „Sieci spoczynkowe a ukierunkowana aktywność poznawcza"). W niniejszym artykule będę używała pierwotnej nazwy („sieci spoczynkowe”) zamiennie ze współczesnym, ogólniejszym określeniem (,sieci funkcjonalne”).

Duży wpływ na szybki rozwój badań dotyczacych architektury funkcjonalnej mózgu miały rosnące możliwości naukowców w dziedzinie formalnego opisu własności sieci. Lata 90. to nie tylko czas ważnych odkryć w badaniach mózgu. W tej dekadzie rozpoczał się również prężny rozwój transdyscyplinarnej nauki o sieciach (ang. network science), na gruncie której wykazano, że bardzo wiele rzeczywistych systemów w różnych dziedzinach życia ${ }^{1}$ przejawia te same nadrzędne zasady organizacji. Postęp $\mathrm{w}$ dziedzinie analizy sieci złożonych, wyrosłej na gruncie ma-

${ }^{1}$ Przykładami systemów, które $z$ powodzeniem bada się $w$ terminach sieci sa $\mathrm{m}$.in. relacje społeczne, połaczenia komunikacyjne i transportowe, wyrażenia językowe czy Internet. tematycznej teorii grafów, wyposażył badaczy $w$ język $i$ narzędzia do opisu $i$ interpretacji własności sieci. W ramach tego podejścia sieci definiuje się jako układ węzłów (podstawowych obiektów włączonych do analizy, np. niewielkich obszarów mózgu) i krawędzi (relacji między węzłami). Analizujacc topologiczne własności tak przedstawionych sieci uzyskuje się m.in. miary segregacji, służące określeniu, w jakim stopniu węzły skupiaja się $\mathrm{w}$ relatywnie odrębne, gęsto wewnętrznie skomunikowane grupy (moduły); miary integracji, służące określeniu, $z$ jaką łatwościa sieć zdolna jest do przekazywania informacji pomiędzy różnymi węzłami i modułami oraz miary centralności, służące identyfikowaniu kluczowych węzłów sieci (ang. hubs), które dzięki swoim połączeniom mają największe znaczenie dla przepływu informacji. Analiza ta pozwoliła opisać połaczenia funkcjonalne mózgu przy pomocy niedużej liczby wskaźników posiadających biologiczną interpretację (przystępne wprowadzenie i opis poszczególnych miar można znaleźć w RUBINOV i SPORNS 2009).

W dalszej części tego szkicu przestawiam najważniejsze badania dotyczące organizacji sieciowej mózgu. W ostatnich dwóch dekadach liczba prac poświęconych tej tematyce rosła tak szybko, że kwestia integracji rozbieżnych niekiedy wyników (uzyskiwanych przy użyciu różnorodnych metod) pozostawała często w tyle. Stąd łatwo napotkać różne definicje poszczególnych sieci i odmienne ich nazewnictwo. Na poczatku postaram się więc uporządkować najważniejsze doniesienia dotyczace sieci i opisać najczęściej wyodrębniane jednostki funkcjonalne mózgu. Następnie przejdę do prób odpowiedzi na pytania o neuronalne podstawy połączeń funkcjonalnych obserwowanych w sygnale BOLD oraz zasady ich organizacji. Przytoczone badania pozwola lepiej zrozumieć ewolucyjne pochodzenie organizacji sieciowej i jej znaczenie dla kształtowania się możliwości poznawczych człowieka.

\section{SIECI WYODREBNIONE W SPONTANICZNEJ AKTYWNOSCI MÓZGU}

Metoda, która leży u podstaw wnioskowania o sieciach funkcjonalnych w mózgu, polega na korelacji przebiegu sygnału BOLD $z$ pewnego małego obszaru mózgu $z$ sygnałem $\mathrm{z}$ wszystkich pozostałych miejsc $\mathrm{w}$ mózgu (tzw. metoda korelacji $z$ wokselem źródłowym; ang. seed-voxel correlations). Jako „mały obszar” źródłowy rozumie się tutaj pojedynczy woksel (trójwymiarowy wycinek obrazu rejestrowanego w MRI, o wielkości wyznaczanej przez rozdzielczość skanu) lub większa liczbę przyległych wokseli de- 
A
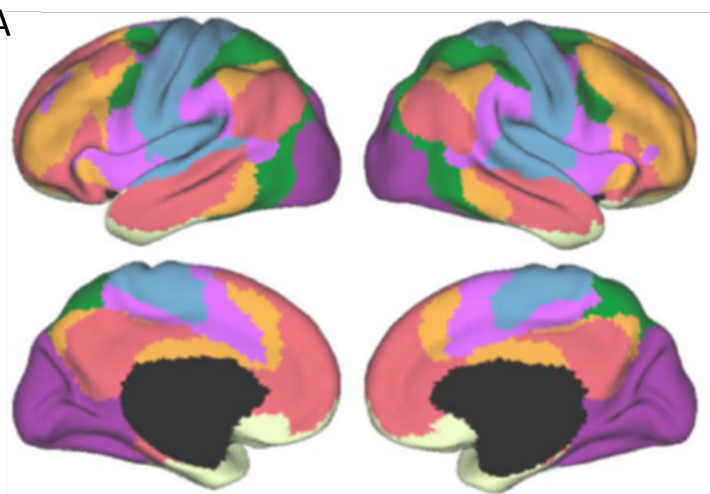

$\square$ grzbietowa sieć uwagowa
$\square$ brzuszna sieć uwagowa
$\square$ sieć czołowo-ciemieniowa
$\square$ sieć aktywności spoczynkowej
$\square$ obszary limbiczne
$\square$ obszary czuciowo-ruchowe i słuchowe
$\square$ obszary wzrokowe
B
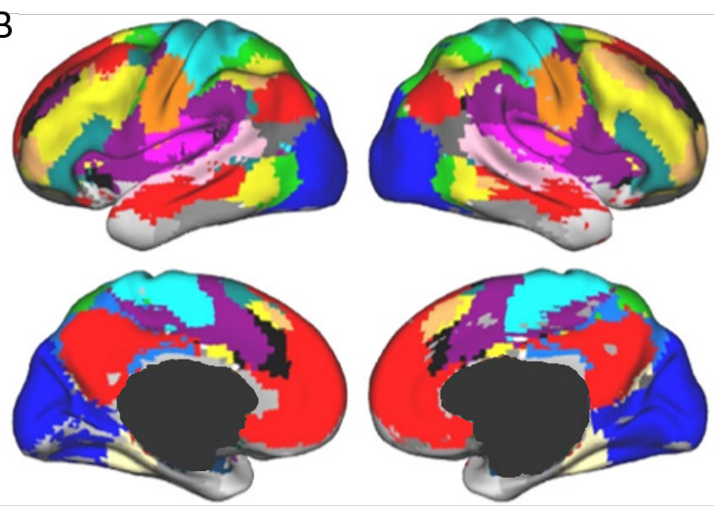

$\square$ grzbietowa sieć uwagowa

$\square$ brzuszna sieć uwagowa

$\square$ sieć czołowo-ciemieniowa

$\square$ sieć aktywności spoczynkowej

sieć istotności

$\square$ sieć obręczowo-wieczkowa

$\square$ obszary czuciowo-ruchowe (ciało)

$\square$ obszary czuciowo-ruchowe (twarz)

$\square$ obszary stuchowe

obszary wzrokowe

Ryc. 1. Sieci funkcjonalne mózgu czlowieka.

A. Podział mózgu na sieci funkcjonalne, dokonany przez YEO i współaut. (2011) za pomoca analizy skupień na danych zebranych od 1000 osób, uwzględniający siedem najbardziej stabilnych sieci B. Podział na sieci dokonany w oparciu o metody grafowe przez Powera i współaut. (2011), na danych zebranych od 100 osób, uwzględniający największą liczbę wyodrębnianych sieci.

finiowanych na podstawie anatomii lub innych badań funkcjonalnych. Korelacje te można przedstawić na powierzchni mózgu, tworzac mapę siły połączen. Mapę korelacji można też ograniczyć do wartości istotnych statystycznie, wskazujących obszary o najsilniejszych połaczeniach. W ten właśnie sposób pokazano, które obszary tworza sieć spoczynkowa ruchu, a następnie, że podobne, wewnętrzne połaczenia funkcjonalne w zakresie wolnych oscylacji zachodza również w korze słuchowej i wzrokowej (Lowe i współaut. 1998, CORDES i współaut. 2000). Przy użyciu tej metody zostały opisane również inne sieci, spoza obszarów zmysłowych i ruchowych, np. grzbietowa i brzuszna sieć uwagowa (Fox i współaut. 2006). Obszary (woksele) źródłowe w tych analizach ustalano na podstawie wyników badań wykorzystujących różne zadania poznawcze. Wyznaczanie sieci na podstawie tak zdefiniowanych obszarów miało swoje ograniczenia: na przykład nie było jasne, czy wyodrębniano $\mathrm{w}$ ten sposób wszystkie sieci występujace w korze. Metoda ta nie pozwalała również stwierdzić, czy obszary źródłowe wybierano w sposób optymalny, to znaczy, czy były one jednorodne pod względem połączeń funkcjonalnych. Dlatego duże znaczenie dla dziedziny badań sieciowych miało zastosowanie analiz, które objęły jednocześnie cały mózg i minimalizowały arbitralność wyboru źródeł (ang. data driven). Te nowe analizy bazowały najczęściej na metodzie korelacji $z$ wokselem źródłowym, aplikowanej jednocześnie do wszystkich miejsc mózgu. Użycie wszystkich wokseli jako wokseli źródłowych, czyli porównanie połączeń funkcjonalnych na zasadzie „każdy z każdym” pozwalało stworzyć macierz korelacji, czyli tzw. konektom funkcjonalny. Na postawie takiej macierzy, poszczególne obszary mózgu były następnie grupowane w sieci przy użyciu różnych metod matematycznych.

Największe znaczenie miały dotychczas dwa podziały, które stały się podstawa popularnych atlasów sieci ${ }^{2}$. Jeden $z$ nich (YEO i współaut. 2011) (Ryc. 1A) wykorzystuje analizę skupień do wyodrębnienia obszarów charakteryzujących się największym podobieństwem połączeń funkcjonalnych. Drugi (POwer i współaut. 2011) (Ryc. 1B) używa w

${ }^{2}$ Inna metoda parcelacji, która była również szeroko stosowana, jest analiza składowych niezależnych (ICA, ang. independent component analysis) (Beckmann i współaut. 2005). Nie doprowadziła ona jednak do powstania jednoznacznych podziałów kory w postaci atlasu. $Z$ jej użyciem wiąże się również konieczność subiektywnej oceny, np. przy tym samym rzędzie analizy można w wyniku otrzymać różne komponenty; badacz musi zdecydować, czy dany komponent zakwalifikować jako sygnał neuronalnego czy pozaneuronalnego pochodzenia (szum). 
tym celu wspomnianych wyżej metod analizy wywodzacych się $z$ teorii grafów.

Obydwa te podejścia pokazały, że na podstawie aktywności spoczynkowej można podzielić korę mózgu w sposób bardziej lub mniej szczegółowy, uzyskując różną liczbę sieci (od kilku do kilkunastu). Każdy $z$ tych stopni podziału cechuje się relatywna stabilnościa (stąd też wybór określonego podziału do dalszych celów pozostaje nadal w rękach badacza). Przejawia się w ten sposób hierarchiczny charakter architektury sieciowej: duże zespoły o podobnej aktywności moga zawierać mniejsze podjednostki. Pomimo wyraźnych podobieństw, niektóre sieci funkcjonalne uzyskane przy pomocy odrębnych metod różnią się nieco pod względem przestrzennym (nawet po uwzględnieniu możliwego zawierania się jednych sieci w innych; Ryc. 1). Zagadnienie optymalnego sposobu podziału („ostatecznej” klasyfikacji) oraz znaczenia różnic uzyskiwanych przy użyciu odmiennych metod obliczeniowych pozostaje otwarte. Atlas YEO i współaut. (2011) wyodrębnia siedem nadrzędnych jednostek funkcjonalnych (tzw. sieć aktywności spoczynkowej, grzbietową sieć uwagową, brzuszną sieć uwagowa, sieć czołowo-ciemieniowa, sieć wzrokową, sieć czuciowo-ruchowo-słuchowa oraz sieć limbiczna) i te właśnie sieci najczęściej identyfikowane są również w innych pracach. Inne jednostki funkcjonalne, które bardzo często przywoływane sa w literaturze, to m.in. sieć obręczowo-wieczkowa czy sieć istotności. Omówię tutaj wszystkie te sieci $[z$ pominięciem obszarów układu limbicznego ${ }^{3}$, który tworzony jest w dużym stopniu przez struktury podkorowe nieujęte $\mathrm{w}$ analizie sieciowej oraz obszarów zmysłowo-ruchowych, które doczekały się już obszernych omówień poza kontekstem sieci (KANDEL i współaut. 2013; rozdz. 27-28, 37-39)], uwzględniając czasem niespójne ich definicje (odmienne granice) i proponowane podziały.

\section{SIEĆ AKTYWNOŚCI SPOCZYNKOWEJ}

Sieć aktywności spoczynkowej (ang. default mode network, DMN) była pierwsza zidentyfikowana długozasięgową (rozległa) siecią mózgu (po omawianych wcześniej i bardziej lokalnych sieciach ruchowych i zmysłowych), rozpoznana już na podstawie badań tomografii pozytronowej (PET) (SHULMAN i współaut. 1997, RAICHLE i współaut. 2001). W jej skład wchodza m.in. przyśrodkowo: tylne części zakrętu obręczy, przedkli-

${ }^{3}$ Obszary znajdujące się w podstawnej części kory czołowej i skroniowej tworzące sieć limbiczna w podziale Yeo i współaut. (2011) cechują się niskim stosunkiem sygnału do szumu; w związku $z$ tym, wg. autorów podziału, ich charakterystyka funkcjonalna wymaga jeszcze dodatkowej weryfikacji. nek i część kory przedczołowej; grzbietowo-bocznie: fragmenty płacika ciemieniowego w okolicy zakrętu katowego oraz fragmenty płatów skroniowych. Zauważono, że aktywność wszystkich tych obszarów wzrastała w okresach kontrolnych eksperymentów, w czasie aktywności spoczynkowej (MAzOYER i współaut. 2001), a obniżała się, gdy osoby badane rozwiazywały zadania przygotowane przez eksperymentatorów (GREICIUS i wspó1aut. 2003). W zwiazku $z$ tym podejrzewano, że aktywność DMN związana jest $z$ procesami zachodzacymi pod nieobecność dobrze określonych zadań poznawczych, np. z wewnętrznym, swobodnym strumieniem myśli, który pojawia się $\mathrm{w}$ stanie zrelaksowania. Tej intuicji sieć zawdzięcza swa nazwę - angielska „default mode network" oznacza stan podstawowy, wyjściowy, niezmodyfikowany. W istocie, w niektórych badaniach większa aktywność DMN korelowała ze zwiększona tendencja do „błądzenia myślami” podczas zadania i $z$ gorszym wynikiem podczas zadań wymagających skupienia (np. WEISSMAN i współaut. 2006, ESTERMAN i współaut. 2013), co sugerowało, że aktywność w obrębie DMN zakłóca ukierunkowane procesy poznawcze. Późniejsze badania wykazały jednak, że DMN może być zaangażowana w rozwiazywanie nawet dobrze ustrukturyzowanych zadań, jeśli wymagają one odnoszenia się do własnej osoby, myślenia o przeszłości czy wyobrażanie sobie przyszłości (SPRENG i współaut. 2010). Podczas gdy przedmiotem większości zadań eksperymentalnych było myślenie "skierowane na zewnattrz", tj. manipulowanie docierajacymi informacjami i dokonywanie przekształceń wzrokowo-przestrzennych, zaangażowanie DMN ujawnia się w myśleniu "skierowanym do wewnattrz", bazującym na zasobach pamięci.

Dalsze badania nad architektura funkcjonalną tej sieci sugerują, że można wyróżnić trzy podsieci w obrębie DMN (ANDREWS-HANNA i współaut. 2010, DIXON i współaut. 2017). Podsieć „osiowa” DMN (ang. DN-core), na która składają się głównie obszary przyśrodkowe, jest najbardziej związana $Z$ myśleniem odnoszacym się do własnej osoby, z narracja na temat ,ja”, osobowych cech, preferencji i autobiograficznych szczegółów. Druga $z$ podsieci, „grzbietowo-przyśrodkowo czołowa" podsieć DMN (ang. dorsomedial prefrontal subsystem, DN-DMPFC) obejmuje rozproszone obszary grzbietowo-boczne w korze ciemieniowej i grzbietowo-przyśrodkowe w korze przedczołowej oraz obszary bocznej kory skroniowej. Jest ona zaangażowana w przetwarzanie informacji o charakterze semantycznym (w tym we wnioskowanie o stanach mentalnych, np. o przekonaniach innych osób). Podsieć „przy- 
środkowo-skroniowa" DMN (ang. medial temporal subsystem, DN-MTL), obejmujaca m.in. część przyśrodkową płata skroniowego, jest najsilniej zwiazana $z$ wyobrażaniem sobie przyszłości i ogólniej, $z$ tworzeniem wyobrażeń i wiązaniem różnych elementów w oparciu o pamięć epizodycznac. W badaniach wykazano ścisły funkcjonalny związek (wysoka korelację aktywności) węzłów osiowych DMN (DN-core) $z$ dwoma pozostałymi podsieciami. Pozostałe dwie podsieci (DN-DMPFC oraz DN-MTL) sa znacznie mniej zależne od siebie i aktywują się rozłacznie w niektórych zadaniach eksperymentalnych.

\section{GRZBIETOWA SIEĆ UWAGOWA}

Grzbietowa sieć uwagowa (ang. dorsal attention network, DAN) została zidentyfikowana jako sieć spoczynkowa w badaniach spontanicznej aktywności mózgu (CORBeTta i współaut. 2008, Fox i współaut. 2006), choć już wcześniej tzw. grzbietowy system czołowo-ciemieniowy opisywany był w licznych badaniach poświęconych kierowaniu uwagi oraz przygotowywaniu reakcji ruchowych (wzrokowych, manualnych) ku obiektom w przestrzeni. DAN obejmuje obszar bruzd śródciemieniowych (ang. intraparietal sulci, IPS) w płacie ciemieniowym, fragment środkowego zakrętu skroniowego (ang. muddle temporal, MT) w płacie potylicznym i przednie pola wzrokowe (ang. frontal eye fields, FEF) w płacie czołowym. Sieć ta bierze udział w koordynowaniu działania oraz przetwarzaniu informacji na temat przestrzennych relacji obiektów i ciała. Aktywność tych obszarów towarzyszy również wzmożonemu skupianiu uwagi, zarówno jeśli chodzi o ukierunkowywanie uwagi w określone miejsce, jak i na określone własności bodźców (takie jak np. kierunek ruchu, orientacja). Obszary DAN biora udział $w$ generowaniu i podtrzymywaniu sygnałów mobilizujacych inne ośrodki, które bezpośrednio odpowiadaja za wykonywanie bieżącego zadania. Postuluje się, że obszary grzbietowe odpowiadaja za "odgórna" (ang. top-down) modulację aktywnych w danym momencie analizatorów (ośrodków przetwarzających informację zmysłowa), ośrodków wykonawczych (potrzebnych do wykonania reakcji ruchowej) oraz ośrodków przechowujacych reprezentację reguł bieżącego zadania (a więc łączących treści i sposoby reagowania). W obrębie DAN zachodzą procesy ważenia informacji o cechach fizycznych środowiska i aktualnych celach behawioralnych, których wynikiem jest wyznaczanie kolejnych celów uwagi (BISLEy i GOLDBERG 2010). Znajdujące się w obrębie DAN zespoły komórkowe, które kodują informację o „ważności” miejsc i obiektów zyskały miano tzw. map istotności (ang. priority maps), określających, gdzie aktualnie powinna zostać skierowana uwaga.

\section{BRZUSZNA SIEĆ UWAGOWA I SIEĆ OBRECZOWO-WIECZKOWA}

Brzuszna sieć uwagowa (ang. ventral attention network, VAN) została opisana wraz z siecia grzbietowa (CORBETTA i współaut. 2008, Fox i współaut. 2006) jako sieć aktywująca się $\mathrm{w}$ reakcji na istotne bodźce środowiskowe, pozostajace poza aktualnym centrum uwagi. Na zbiór obszarów należacy do brzusznej sieci uwagowej składają się części środkowego i dolnego zakrętu czołowego (ang. ventral frontal cortex, VFC) oraz styk skroniowo-ciemieniowy (ang. temporoparietal junction, TPJ) w bocznej części płata ciemieniowego, obejmujacy fragment zakrętu kątowego (ang. angular gyrus, AG), zakrętu nadbrzeżnego (ang. supramarginal gyrus, SMG) i górnego zakrętu skroniowego (ang. superior temporal gyrus, STG) (zakresy brzusznej sieci uwagowej, przedstawione na Ryc. 1, nie odpowiadaja dokładnie przytoczonej, pierwotnej definicji). Nazwa brzusznej sieci uwagowej odnosi się więc do położenia względem sieci grzbietowej, a nie do położenia na brzusznej powierzchni mózgu. Co ciekawe, w przypadku tej sieci podkreśla się jej prawostronna lateralizację, a więc obejmuje ona w większym stopniu obszary prawej półkuli mózgu. Liczne badania wykazały, że aktywność tych obszarów ujawnia się, gdy bodziec docelowy pojawia się $\mathrm{w}$ innym miejscu niż to, na które skierowana jest uwaga (CORBETTA i SHULMAN 2002). Pierwotna hipoteza ujmująca rolę brzusznej sieci uwagowej mówiła, że obszary te pełnią funkcję "zwrotnicy”, ośrodka, który pod wpływem nowych, wyrazistych sygnałów ze środowiska przekierowuje czynności obszarów grzbietowych na przetwarzanie zwiazane z nowymi bodźcami. Teoria ta spotkała się jednak z krytyka (GENG i Vossel 2013, MACALUSO i DORICCHI 2013), m.in. w zwiąku $z$ faktem, że sygnały rejestrowane w okolicy styku skroniowo-ciemieniowego pojawiaja się zbyt późno, by inicjować zmiany zachodzace w DAN. Choć wielu badaczy uznaje, że aktywność VAN dotyczy także bodźców, które nie powoduja przekierowania uwagi w przestrzeni, ale ze względu na swój niespodziewany charakter wymagaja aktualizacji uwagi w bardziej abstrakcyjnym wymiarze, w ostatnich latach hipoteza ta była również podważana (IGELSTRÖM i GRAZIANO 2017, JUREWICZ 2019). Tak więc, funkcja brzusznej sieci uwagowej oczekuje jeszcze na ostateczna weryfikację. 
Brzuszną siecią uwagowa został nazwany również jeden $z$ zespołów funkcjonalnych wyodrębnionych przez YEO i współaut. (2011) (Ryc. 1A), chociaż nie jest on tożsamy $z$ siecia zdefiniowana przez CORBETTE i współaut. (2008). Obszary zajmowane przez VAN w podziale YEO i współaut. (2011) sa znacznie bardziej rozległe i obejmuja obustronnie obszary styku skroniowo-ciemieniowego, wyspy i dolnego zakrętu czołowego oraz fragmenty dodatkowej kory ruchowej i grzbietowej części przedniego zakrętu obręczy. Prawdopodobnie pierwotnie opisywana brzuszna sieć uwagowa (CORBETTA i współaut. 2008) stanowi tylko część (podsieć) brzusznej sieci uwagowej wyznaczonej przez grupę Yeo. Obszary tej podsieci w większym stopniu pokrywaja się $z$ siecia obręczowo-wieczkowa (ang. cingulo-opercular network, CON) opisana najpierw $w$ pracach DOSENBACHA i współaut. (2006) i widoczną również w podziałach POWERA i współaut. (2011). Wykazano, że aktywność w obrębie CON wzrasta fazowo $\mathrm{w}$ momencie inicjowania oraz kończenia określonej czynności, utrzymuje się także na podwyższonym poziomie przez cały czas jej trwania. Sugeruje to, że CON ma ważny wkład we wdrażanie i utrzymywanie określonej zasady działania oraz $\mathrm{w}$ przełączanie się pomiędzy zadaniami. Najprawdopodobniej to właśnie reakcja $\mathrm{w}$ obrębie CON była obserwowana w okolicy styku skroniowo-ciemieniowego $\mathrm{w}$ następstwie pojawiania się rzadkich bodźców w zadaniach typu „oddball”, które nie wymagaja przekierowywania uwagi $\mathrm{w}$ przestrzeni (IGELSTRÖM i GRAZIANO 2017). Najprawdopodobniej VAN zidentyfikowana $w$ pracach CORBETTY i współaut. (2008) oraz CON wspólnie tworza VAN wg. szerokiego podziału YEO i współaut (2011). Możliwe, że właśnie $z$ powodu bliskości przestrzennej tych sieci i ich utożsamienia, w niektórych badaniach pojawia się brak spójności $\mathrm{w}$ doniesieniach na temat roli brzusznej sieci uwagowej w przekierowywaniu uwagi.

\section{SIEĆ CZOŁOWO-CIEMIENIOWA I SIEĆ ISTOTNOŚCI}

Sieć czołowo-ciemieniowa (ang. fronto-parietal network, FPN), określana w literaturze również jako sieć kontrolna czołowo-ciemieniowa (ang. fronto-parietal control network, FCN), sieć wykonawcza (ang. central executive network, CEN) lub sieć kontroli poznawczej (ang. cognitive control network, $\mathrm{CCN}$ ), jako ostatnia doczekała się opisu w kategoriach sieciowych (COLE i SCHNEIDER 2007, Vincent i współaut. 2008). Przyczynić się do tego mógł zróżnicowany stopień aktywacji poszczególnych węzłów tej sieci $\mathrm{w}$ odmiennych zadaniach poznawczych oraz ich udział w różnych kontekstach funkcjonalnych. Sieć ta obejmuje rozległe obszary grzbietowo-bocznej kory przedczołowej (ang. dorsolateral prefrontal cortex, DLPFC) oraz dolnego płacika ciemieniowego (ang. inferior parietal lobule, IPL), fragmenty przedniej wyspy (ang. anterior insula, AI), a przyśrodkowo fragment dodatkowej kory ruchowej (ang. pre-supplementary motor area, pre-SMA) i przedniej części zakrętu obręczy (ang. anterior cingulate cortex, $\mathrm{ACC}$ ).

Ze względu na lokalizacje obszarów FPN pomiędzy obszarami DAN i DMN przypuszczano, że sieć czołowo-ciemieniowa ma za zadanie integrację informacji przetwarzanych w obu tych sieciach lub (ze względu na postrzeganie DAN i DMN jako pozostajacych w opozycji, por. poniżej) regulacje ich wzajemnej aktywacji. W najnowszych analizach, w obrębie FPN wyodrębniono dwie podsieci (DIXON i współaut. 2018). Ich anatomiczne rozdzielenie nie jest łatwe, ponieważ niemal każdy $z$ przestrzennie odrębnych regionów FPN obejmuje elementy obydwu podsieci. Klarowny jest za to ich podział funkcjonalny: jedna część jest bliżej funkcjonalnie związana $z$ siecią DMN, a druga $z$ siecia DAN. Regiony należące do tych dwu części FPN charakteryzuje istotnie wyższa korelacja $z$ obszarami albo DMN albo DAN, ale najlepiej koreluja one pomiędzy soba, potwierdzając $w$ ten sposób odrębność funkcjonalna całego FPN. Aktywność sieci czołowo-ciemieniowej obserwuje się często w zadaniach obciązających tzw. pamięć robocza, a więc $\mathrm{w}$ zadaniach, które wymagaja zapamiętania określonego zbioru elementów i dokonywania przekształceń „w pamięci” (KROGER i współaut. 2002, EGLI i współaut. 2018).

FPN w swoim „maksymalnym” zakresie, wyznaczonym przez podział YEO i współaut. (2011), prawdopodobnie obejmuje również tzw. sieć istotności (ang. salience network, SN), wyróżniona pierwotnie przez SEELEYA i współaut. (2007) i obecna również w podziałach POwERA i współaut. (2011). Do sieci istotności zalicza się obszary grzbietowe przedniej części zakrętu obręczy i obszary w przedniej części wyspy (obustronnie). Nie jest do końca jasne, jakie sa unikatowe funkcje sieci istotności. Postuluje się, że rola tej sieci jest wzbudzanie i koordynowanie reakcji na wyraziste bodźce. Wiązano ją również $z$ procesami wymagajacymi wysiłku i kontroli poznawczej, np. przy rozwiązywaniu skomplikowanych zadań, w sytuacji konfliktu reakcji czy konieczności powstrzymania się od działania [(DUNCAN i OWEN 2000); nieco inne wyjaśnienie zaproponowali YARKONI i współaut. (2009)]. O zaangażowaniu sieci 
istotności wnioskowano najczęściej w oparciu o obserwacje dotyczące grzbietowych fragmentów przedniej części zakrętu obręczy. Niestety, na podstawie samej tylko lokalizacji anatomicznej, trudno rozróżnić zaangażowanie sieci istotności i sieci obręczowo-wieczkowej, których fragmenty znajduja się blisko siebie w centralnych obszarach przyśrodkowej powierzchni mózgu.

Wczesne prace dotyczace sieci spoczynkowych wyróżniały również sieć „aktywującą się w zadaniach" (ang. task-positive network) i sieć „dezaktywujacca się w zadaniach" (ang. task-negative network) (Fox i współaut. 2005). Pierwsza z nich obejmowała obszary grzbietowej sieci uwagowej, w jej skład wchodziły również obszary sieci obręczowo-wieczkowej. Sieć „dezaktywująca się w zadaniach" była tożsama $z$ siecia aktywności spoczynkowej. Określenie tych systemów jako przeciwstawnych miało za przesłankę fakt, że sygnał spoczynkowy obydwu tych sieci przejawiał wysoka ujemna korelację w czasie. Wzrost sygnału w sieci „aktywującej się w zadaniach" oznaczał więc spadek sygnału w sieci "dezaktywujacej się w zadaniach" i na odwrót. Niedawne badania wykazały jednak, że postrzeganie tych obszarów jako pozostajacych we wzajemnej opozycji jest nieuprawnione - ujemny znak tej korelacji okazał się być skutkiem ubocznym stosowanego powszechnie sposobu przetwarzania danych, który obejmuje usunięcie średniej wartości sygnału (metoda regresji, ang. global mean regression). DAN i DMN pozostaja raczej niezależne wobec siebie niż ujemnie skorelowane, a słaba, odwrotna zależność względem DAN dotyczy jedynie osiowych obszarów DMN (DIXON i współaut. 2017). Wyróżnienie dwóch nadrzędnych systemów jest jednak o tyle ważne, że przejawia się w nim wspominana wcześniej hierarchiczność podziału wzorców aktywności sieci, tj. grupowanie się sieci w większe systemy. Dychotomiczny podział aktywności spoczynkowej grupuje ze soba DAN i obszary funkcjonalnie bliższe tej sieci: korę czuciowo-ruchowa, korę wzorkową, brzuszną sieć uwagowa/ sieć obręczowo-wieczkową, $z$ drugiej strony łaczac ze sobą DMN i obszary, które wykazuja pozytywne związki $z$ ta siecia, należace do sieci czołowo-ciemieniowej (Doucet i współaut. 2011). Obecnie więc, zamiast o aktywacji i dezaktywacji tych sieci podczas wykonywania zadań, mówi się raczej o systemach przetwarzania „zewnętrznego" (ang. intrinsic) i „wewnętrznego" (ang. extrinsic), które różnia się stopniem, w jakim integrują informacje pochodzace ze środowiska zewnętrznego.

\section{SIECI SPOCZYNKOWE A UKIERUNKOWANA AKTYWNOŚĆ POZNAWCZA}

Zawarte w poprzednim rozdziale omówienie sieci spoczynkowych pokazuje, że aktywność spoczynkowa grupuje obszary spójne pod względem pełnionych funkcji. Jaki jest więc związek między aktywnością mózgu w stanie spoczynku i podczas działania? Wykonywanie określonych zadań poznawczych powoduje wzrost aktywności poszczególnych, czasem bardzo niewielkich obszarów kory, w wielu odmiennych konfiguracjach, specyficznych dla danego zadania. Współczesne badania metaanalityczne wykazały jednak, że miejsca aktywacji charakterystyczne dla różnych funkcji (takich jak uwaga, rozumowanie, pamięć, słyszenie, emocje itd.), zagregowane na przestrzeni setek lub tysięcy badań, odtwarzaja układ przestrzenny głównych sieci rozpoznanych w badaniach aktywności spoczynkowej (SMITH i współaut. 2009, YARKONI i współaut. 2011). W jaki sposób należy więc rozumieć to, że sieci aktywują się w "całości" w stanie spoczynkowym i „w części” w poszczególnych zadaniach (a przynajmniej tak się na pierwszy rzut oka wydaje)? W jaki sposób wiedzę o funkcjonalnie zintegrowanych sieciach spoczynkowych można połaczyć $z$ przekonaniem, że to właśnie różnorodność konfiguracji połaczeń funkcjonalnych pozwala nam doświadczać tak wielu odmiennych procesów poznawczych?

Po pierwsze, należy zauważyć, że większość badań neuroobrazowych opiera się na porównywaniu aktywności mózgu pomiędzy sytuacja, w której dany proces poznawczy zachodzi, a taka, w której on nie występuje. Tego rodzaju badania skoncentrowane sa na "wierzchołku góry lodowej" - drobnych zmianach aktywności wywołanych określonym procesem. Tymczasem to, co jest wspólne w porównywanych ze soba sytuacjach, pozostaje zwykle poza polem widzenia badaczy. Aby odpowiedzieć na zadane wyżej pytania, należy zaś porównać cała aktywność mózgu. W jednej $z$ takich analiz COLE i współaut. (2014) wykorzystali zbiór danych obejmujacy kilkadziesiąt różnych zadań wykonywanych w skanerze fMRI i rejestracje spontanicznej aktywności mózgu (sygnał <0,08 Hz) do sprawdzenia, w jakim stopniu aktywność mózgu w czasie określonych czynności różni się od aktywności spoczynkowej. Porównujac macierze korelacji sygnału BOLD pokazali oni, że średni wzorzec połaczeń funkcjonalnych w całym mózgu podczas wykonywania zadań jest 
w ok. $80 \%$ taki sam $(r=0,9)$, jak wzorzec połączeń w stanie spoczynku (a przy porównaniu kolejno pojedynczych badań podobieństwo wynosiło średnio ok. $70 \%$, $\mathrm{r}=0,84)$. Podobne badania wykonane przez KRIENEN i współaut. (2014) pokazały, że sieci, wyodrębnione $\mathrm{w}$ kilkunastu różnych zadaniach (przy użyciu tych samych metod, których wcześniej użyto do dzielenia aktywności spoczynkowej) sa bardzo do siebie podobne. Wśród zastosowanych zadań znajdowało się również zadanie biernego patrzenia na punkt fiksacji, czyli po prostu stan spoczynkowy. Porównanie parami (łącznie aż 91) wszystkich tych czynności pokazało, że korelacja wzorców sieci mieści się w dość waskim zakresie $[z(r)=0,69-0,82]$ i jest nieco większa dla zadań należących do wspólnej kategorii (np. zadania $\mathrm{z}$ i bez stymulacji zmysłowej, zadania oparte o material słowny itp.), a mniejsze pomiędzy nimi. Co więcej, w innych badaniach pokazano też, że różnice międzyosobnicze w układzie i funkcjonowaniu sieci przewyższają różnice wynikajace $z$ wykonywania określonych czynności i czynników sytuacyjnych (GRATTON i współaut. 2018); układ sieci stanowi więc relatywnie stałą charakterystykę każdej osoby.

Oznacza to, że połączenia funkcjonalne w mózgu sa w każdym momencie raczej stałe, ale właśnie ten drobny procent zmienności stanowi o zróżnicowanych czynnościach umysłowych i behawioralnych. Choć połączeń funkcjonalnych nie da się $\mathrm{w}$ prosty sposób wyznaczyć poprzez rekonstrukcję połaczeń strukturalnych ${ }^{4}$, architektura funkcjonalna kształtowana jest przez jej strukturalne podłoże. Ograniczenia strukturalne można postrzegać jako „dyspozycje”, które wyznaczaja możliwe stany sieci w różnych kontekstach. Co ważne, zakres zmienności połączeń funkcjonalnych między zadaniami nie jest jednorodny dla wszystkich części kory. Połaczenia funkcjonalne niektórych obszarów mózgu, np. kory czuciowo-ruchowej, fragmentów dolnego płacika ciemieniowego czy tylnej części wyspy, pozostaja dość podobne $\mathrm{w}$ różnych zadaniach. Połączenia funkcjonalne innych obszarów, np. kory przedczołowej, fragmentów płacika ciemieniowego górnego czy przedniej wyspy, wykazuja znacznie większy zakres zmienności pomiędzy różnymi zadaniami. Zostanie to jeszcze

${ }^{4}$ Obszary wykazujace połaczenie funkcjonalne moga nie mieć ze soba (bezpośrednich) połączeń neuronalnych; synchroniczna aktywność dwóch anatomicznie odrebnych ośrodków może być indukowana poprzez sygnał z innego, wspólnego źródła i/lub połączenia wielosynaptyczne (przez struktury pośrednie). szerzej omówione w rozdziale poświẹconym organizacji mózgowej sieci funkcjonalnych.

Przywołane badania pokazały, że żadne $z$ zadań nie może odgrywać roli wzorca, wyróżnionego stanu, od którego pozostałe tylko się „odchylaja”. Oznacza to, że również stan spoczynkowy nie jest uprzywilejowany względem innych stanów umysłu ${ }^{5}$, choć właśnie $\mathrm{w}$ ten sposób zwykło się o nim myśleć. Na gruncie porównań statystycznych połaczenia funkcjonalne wyznaczone w określonym zadaniu (np. w zadaniu klasyfikacji słów pod względem semantycznym) będa (średnio) równie dobrze przewidywały połączenia funkcjonalne $\mathrm{w}$ innych zadaniach, co stan spoczynkowy. Podsumowując, aktywność w zadaniach to nie tyle zaangażowanie części sieci „dodane" do podstawowej "masy” aktywności spoczynkowej, co modulacja aktywności wokół wspólnego wzorca, który stanowi stabilna charakterystyke danego mózgu, zakorzeniona $\mathrm{w}$ jego strukturze anatomicznej (również w przypadku stanu spoczynkowego).

\section{AKTYWNOŚĆ NEURONALNA STOJACA ZA SPONTANICZNYMI ZMIANAMI BOLD}

Fakt, że synchroniczne, wolne fluktuacje sygnału BOLD występuja w obrębie obszarów o podobnej roli funkcjonalnej jest sam w sobie źródłem silnej intuicji, że obserwowane korelacje maja źródło w aktywności układu nerwowego. Jednak sygnał BOLD, mierzony w skanerze MR, jest tylko pośrednim wskaźnikiem aktywności neuronalnej. Dostępność utlenowanej krwi w różnych obszarach mózgu zależy od zmian objętości naczyń (wazodylatacji), a te moga być zakorzenione $\mathrm{w}$ autoregulacji samego tylko układu krwionośnego lub w odziaływaniu innych, pozaneuronalnych czynników. Wolne oscylacje wyznaczajace wzorce sieci zidentyfikowano dopiero $\mathrm{w}$ sygnale BOLD, a nie

\footnotetext{
${ }^{5}$ Stan spoczynkowy jest uprzywilejowany na gruncie badań neuroobrazowych w innym, praktycznym sensie. Po pierwsze, istnieje już znacznie więcej badań na temat połączeń funkcjonalnych mózgu opartych o stan spoczynkowy. Po drugie, różnym grupom badaczy łatwiej jest wzajemnie porównać swoje wyniki, jeśli zostaną one uzyskane w ramach tego samego stanu mentalnego/behawioralnego: stan spoczynkowy idealnie nadaje się jako takie powszechne „zadanie” aplikowane osobom badanym w skanerze MRI. W tym celu należałoby jednak jeszcze lepiej sprecyzować definicję stanu spoczynkowego. Nawet na gruncie badań „spoczynkowych” opisano już występowanie różnic pomiędzy wzorcami przestrzennymi sieci, jeśli pomiary różniły sie dokładna treścią instrukcji zalecającej stan spoczynkowy (np. „postaraj się nie myśleć o niczym” versus „pozwól swoim myślom błądzić", Kawagoe i współaut. 2018). Podobnie znaczenie ma to, czy badani mieli oczy zamknięte czy otwarte oraz czy fiksowali wzrok na określonym punkcie (Patriat i współaut. 2013).
} 
były wcześniej opisywane w pomiarach elektrofizjologicznych, co pokazuje, że ich mechanizm nie był łatwy do uchwycenia.

Najbardziej podstawowe kwestie, dotyczace źródeł i znaczenia oscylacji spoczynkowych powracaja najczęściej w postaci dwóch rodzajów pytań. Po pierwsze, czy zmiany spoczynkowe odzwierciedlaja faktycznie aktywność neuronalną? Po drugie, jeśli źródłem tych zmian jest aktywność neuronów, to jaki jest jej mechanizm? Mimo że fluktuacje spoczynkowe sa obecnie przedmiotem tak wielu badań, kwestie te nie doczekały się jeszcze jednoznacznego rozstrzygnięcia i przez cały czas pozostaja przedmiotem ożywionej dyskusji.

Wśród wczesnych badań prowadzonych przez BISWALA i współaut. (1997) znalazły się testy, w których manipulowano zwiazkiem między metabolizmem komórkowym a natlenowaniem krwi (m.in. poprzez hiperkapnię, czyli zwiększenie stężenia $\mathrm{CO}_{2}$ we krwi, które zwiększa przepływ krwi w naczyniach). Zwiększenie przepływu krwi bez towarzyszacych zmian metabolizmu w komórkach nerwowych osłabiało połaczenia funkcjonalne, co sugerowało, że zmiany hemodynamiczne w oderwaniu od procesów nerwowych nie moga wyjaśnić obserwowanych fluktuacji w sygnale. Inni badacze podkreślali również, że obszary skorelowanej aktywności sa na tyle odległe przestrzennie, że nie obejmuja ich te same odgałęzienia naczyń krwionośnych (np. naczynia odpowiedzialne za ukrwienie kory czuciowo-ruchowej obydwu półkul mają połaczenie dopiero na poziomie koła tętniczego Willisa) (SHMUEL i LEOPOLD 2008). Jednak najczęściej o neuronalnych źródłach aktywności spoczynkowej wnioskuje się na postawie badań elektrofizjologicznych, głównie w oparciu o inwazyjne metody rejestracji wewnattrzczaszkowej w badaniach na zwierzętach, a także u osób oczekujących na zabiegi neurochirurgiczne ${ }^{6}$. W badaniach tych rejestruje się przede wszystkim potencjały polowe, czyli zbiorcze pole elektryczne wytwarzane przez populacje komórek. Moga być one lokalne (ang. local field potentials, LFP) w przypadku elektrod umiejscowionych wewnątrztkankowo i na powierzchni mózgu (w elektrokortykografii, ECoG) lub obejmować duże części kory w przypadku elektrod umiejscowionych na powierzchni skóry czaszki (w elektroencefalografii, EEG). Ba-

${ }^{6}$ Próbuje się również rozpoznać aktywność sieci spoczynkowych u ludzi metodami nieinwazyjnymi, tj. za pomoca EEG i MEG, choć otrzymywane wyniki cechuja się znacznie niższa precyzją ze względu na „mieszanie się” sygnałów pochodzących $z$ różnych źródeł na powierzchni czaszki. Ustalenie tzw. map spektralnych jako identyfikatorów sieci (ang. spectral fingerprints) stanowi jedno $z$ wyzwań współczesnej neuronauki (por. Mantini i współaut. 2007, Keitel i Gross 2016, Komorowski i współaut. 2018). dania na myszach i małpach pokazały, że lokalne potencjały polowe w częstotliwości pasma gamma (ok. 60-130 Hz) wykazuja podobne zmiany $\mathrm{w}$ funkcjonalnie połaczonych obszarach (np. w symetrycznych obszarach kory zmysłowej) (SHMUEL i LEOPOLD 2008, ScHÖLVINCK i współaut. 2010). Skorelowane zmiany wysokoczęstotliwościowego LFP w obrębie różnych sieci funkcjonalnych wykazano również $\mathrm{w}$ badaniach $\mathrm{z}$ udziałem ludzi, w oparciu o pomiar ECoG (HACKER i współaut. 2017, KUCYI i współaut. 2018). Synchroniczna aktywność obszarów w sieci opiera się nie tyle na bezpośredniej (fazowej) synchronizacji oscylacji gamma, co na powolnych, synchronicznych zmianach mocy tego pasma. Podobieństwo zmian lokalnych potencjałów polowych obserwuje się więc po wyfiltrowaniu sygnałów w paśmie częstotliwości gamma i analizie ich obwiedni (ang. band-limited power, BLP).

Niedawne badania pacjentów $z$ epilepsja, porównujace przestrzenne wzorce aktywności elektrofizjologicznej i hemodynamicznej pokazuja też, że wolne zmiany mocy sygnału dotycza nie tylko pasma gamma, ale też wolniejszych częstotliwości, w szczególności pasma theta $(4-8 \mathrm{~Hz})$ i alfa $(8-12 \mathrm{~Hz})$. W badaniach HACKERA i współaut. (2017) elektrody położone na powierzchni mózgu pacjentów (umieszczone w wybranych miejscach ze względów medycznych) pokrywały fragmenty sieci DMN, FPN, DAN i SMN. Korelacje zmian mocy sygnału w zakresie pasma theta $\mathrm{i}$ towarzyszace im zmiany pasma gamma zaobserwowano w obrębie DMN i FPN. Korelacje w zakresie pasma alfa wraz $z$ towarzyszacymi zmianami pasma gamma dotyczyły obszarów DAN i SMN. Wyniki te przekładały się więc na rozróżnienie dotyczace przynależności sieci do systemów „wewnętrznego" i „zewnętrznego”. Autorzy pracy sugeruja, że jednoczesne zmiany mocy w obrębie pasm theta i alfa oraz gamma stanowia przykład sprzężenia pomiędzy faza i amplituda (odpowiednio: niższych i wyższych częstości, ang. phase-amplite coupling), obecnego nawet w wolnych fluktuacjach spoczynkowych. Spojrzenie przez pryzmat tej organizacji na wiele wcześniejszych doniesień badawczych daje mocne empiryczne wsparcie hipotezie o specyficznych częstotliwościach charakteryzujacych nadrzędne systemy funkcjonalne. Zmiany aktywności w paśmie theta opisuje się w badaniach nawigacji przestrzennej, pamięci epizodycznej, języka, pamięci roboczej i sytuacji konfliktu między bodźcami i/lub reakcjami. Funkcje te łączą się ze wzmożona aktywnościa zakrętów przyhipokampalnych, skroniowych, przyśrodkowych w okolicy przedklinka i przedniej części kory obręczy, zawierajacych się w obrębie DMN i FPN, a 
więc w sieciach systemu „wewnętrznego". Spadek aktywności w paśmie alfa towarzyszy przetwarzaniu informacji wzrokowej, słuchowej, czynnościom ruchowym i skupianiu uwagi. Reagowanie na bodźce pojawiajace się w środowisku angażuje, poza obszarami zmysłowymi i czuciowo-ruchowymi, sieć DAN, należaca do systemu „zewnętrznego".

Podczas gdy LFP w większym stopniu reprezentuje sygnały przychodzace do danego obszaru mózgu (potencjał ten odzwierciedla sumę potencjałów postsynaptycznych w miejscu rejestracji), aktywność czynnościowa (ang. multiunit activity, MUA), która ma swoje źródło w komórkach badanego obszaru, obrazuje informację wyjściowa. Spontaniczne zmiany w liczbie potencjałów czynnościowych również koreluja $z$ wolnymi zmianami sygnału BOLD. MA i współaut. (2016) mierzyli jednocześnie aktywność neuronalna i hemodynamiczna (metodami obrazowania optycznego, czyli rejestrujac sygnały świetlne zwiazane z aktywnością elektryczna oraz przepływ krwi w badanym fragmencie mózgu odpowiednio genetycznie modyfikowanej myszy). Wykazali oni ścisły związek między liczba potencjałów czynnościowych powstajacych spontanicznie w populacji neuronów pobudzeniowych kory czuciowo-ruchowej a aktywnościa hemodynamiczna w tym samym obszarze. Fluktuacje hemodynamiczne związane $z$ aktywnością czynnościowa wyznaczały rozległe przestrzennie, symetryczne obszary synchronizacji ${ }^{7}$.

Mimo że wiele różnych badań potwierdziło związek pomiędzy wolnymi fluktuacjami BOLD a aktywnościa komórek nerwowych, otrzymane wyniki różnią się znacznie wykazywanym stopniem korelacji między obydwoma sygnałami. W badaniach, w których uzyskano największe korelacje sygnał elektryczny wyjaśniał nawet 50-65\% wolnych fluktuacji sygnału BOLD $(\mathrm{r}=0,7-0,8)$ (MA i współaut. 2016, MATEO i współaut. 2017). Tymczasem w innych badaniach aktywność neuronalna miała tylko drobny udział w całkowitej zmienności amplitudy BOLD (ok. 10\%, r=0,25-0,37) (WINDER i współaut. 2017). Dla porównania, w przypadku odpowiedzi neuronalnych wywołanych bodźcem, aktywność elektryczna odpowiada nawet za 90\% zmienności sygnału BOLD $(r=0,88-0,95)$ (LOGOTHETIS i współaut. 2001, WINDER i współaut. 2017). Tak niewielki wkład sygnału pochodzenia neuronalnego sugeruje, że obserwowane

${ }^{7}$ Dyskusja na temat wkładu LFP i MUA w aktywność obserwowana w badaniach fMRI dotyczy sygnału BOLD w ogólności, nie tylko w kontekście wolnych fluktuacji spoczynkowych (Burns i współaut. 2010). wolne zmiany hemodynamiczne mogą mieć również inne źródło.

W tym kontekście istotne sa doniesienia o fluktuacjach w poziomie ciśnienia krwi, które można zaobserwować w całym układzie krwionośnym, nawet w jego peryferycznych częściach (na przykład w opuszkach palców). Źródła tych fluktuacji, nazywanych również falami Mayera, pozostaja jak dotąd nieznane. Fluktuacje te maja podobna częstotliwość, co spoczynkowe wolne zmiany sygnału BOLD (TONG i współaut. 2015, LACHERT i współaut. 2019). Niektórzy badacze sugerują, że skorelowana aktywność różnych obszarów mózgu może być wynikiem tych ogólnoustrojowych fluktuacji (ToNG i współaut. 2010, 2015, 2019, DREW 2019) oraz drobnych opóźnień przepływu krwi, wynikających $z$ właściwości układu naczyniowego w różnych obszarach mózgu. Badacze sceptyczni wobec „neurocentrycznego" postrzegania wolnych fluktuacji sygnału BOLD podkreślają różnice pomiędzy sygnałem „wywołanym” warunkami zadania, a wolnymi, spontanicznymi fluktuacjami i sugeruja, że związek pomiędzy poziomem sygnału BOLD a aktywnością neuronów może dotyczyć tylko pobudzeń związanych $z$ jawnym zachowaniem/stymulacjac. W badaniu WINDERA i współaut. (2017) na korze czuciowej (baryłkowej) myszy pokazano, że najniższy związek spontanicznych aktywności: neuronalnej i hemodynamicznej, charakteryzuje "czysty stan spoczynkowy”, w którym nie obserwowano żadnej aktywności ruchowej wąsów (wibrysów) zwierzęcia. W przeciwieństwie do tego stanu okresy spoczynkowe zawierajace krótkie, sporadyczne poruszenia wibrysów wykazywały już znacznie wyższa korelację sygnałów neuronalnych i hemodynamicznych. Na tej podstawie autorzy sugeruja, że dotychczasowe badania stanu spoczynkowego mogły niedostatecznie uwzględniać tego rodzaju drobne przejawy aktywności ruchowej i przez to uznawać za "spontaniczne" wzbudzenia zwiazane $z$ występująca okazjonalnie aktywnościa zwierzęcia. Większość badań, zarówno na zwierzętach, jak i na ludziach, rzeczywiście poprzestaje na ogólnym unieruchomieniu, nie monitorujac drobnych, spontanicznych skurczów mięśni, poruszeń palców itp. Z drugiej strony, tego rodzaju samoczynne zachowania, niewywołane zewnętrzna potrzeba, moga stanowić odbicie spontanicznych wyładowań neuronalnych (to samo dotyczy "czynności” umysłowych nieodzwierciedlonych w zachowaniu, takich jak skupianie się czy przypominanie sobie) (por. GELBARD-SAGIV i współaut. 2008) ${ }^{8}$.

${ }^{8}$ Pełny przegląd doniesień poddających w wattpliwość neu- 
A

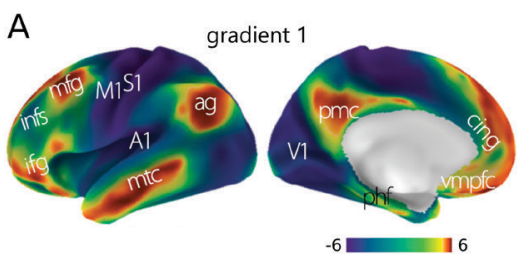

B

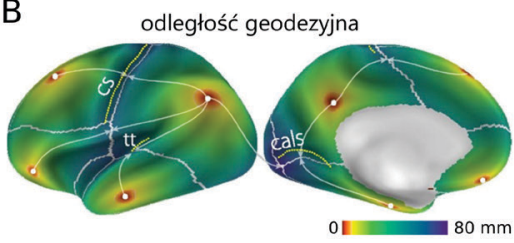

C

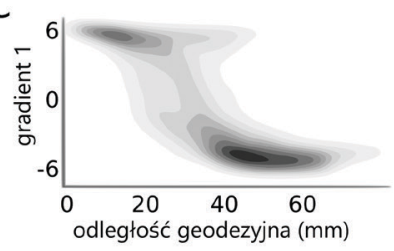

D

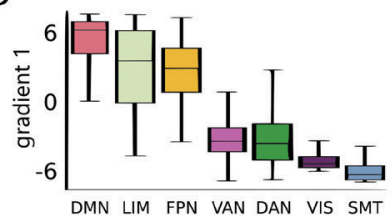

$E$
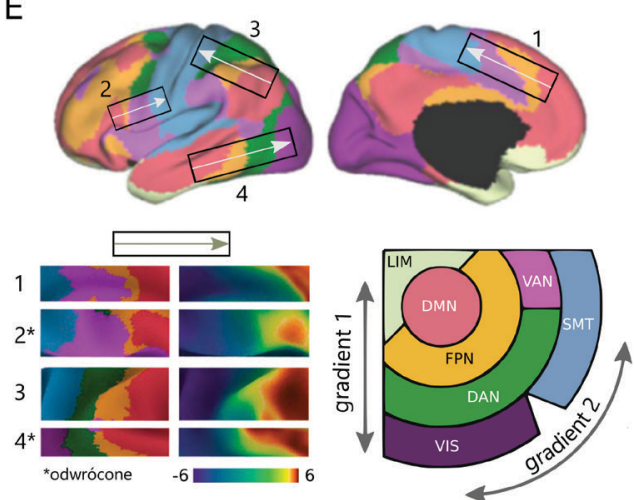

Ryc. 2. Zależność między segregacją funkcjonalną i strukturalna obszarów mózgu oraz organizacja przestrzenna sieci.

A. Wartości gradientu 1. przedstawione na powierzchni bocznej i przyśrodkowej lewej półkuli. Najwyższe wartości, reprezentowane kolorem czerwonym, odtwarzaja rozkład przestrzenny DMN. B. Odległość geodezyjna przedstawiona na wygładzonej powierzchni lewej półkuli mózgu (powierzchnia została „napompowana” w celu ukazania obszarów leżących wewnątrz bruzd kory). Jasnoszare linie wskazuja miejsca w równej odległości od centrów DMN (dystans zaznaczony strzałkami). Przerywanymi żółtymi liniami zaznaczono bruzdę centralną, szczelinę boczną i bruzdę ostrogowa, czyli najważniejsze linie podziału morfologicznego mózgu. Bruzdy te są równo i maksymalnie odsunięte od centrów DMN. C. Wykres obrazujący rozkład wartości gradientu 1. względem odległości geodezyjnej od punktów o najwyższej wartości gradientu 1. D. Wykres przedstawiający wartości gradientu w obrębie siedmiu sieci wyróżnionych przez YEO i współaut. (2011). E. Układ przestrzenny sieci na przykładzie czterech prostokątnych wycinków, wybranych na odcinkach charakteryzujących się stopniowym spadkiem gradientu 1 (zgodnie z szarymi strzałkami zaznaczonymi w B). Układ sieci można podsumować poprzez przedstawienie go na dwuwymiarowym wykresie, uwzględniającym miejsce na osi gradientu 1. i 2. Części A-E zostały zaadaptowane z pracy MARGULIESA i współaut. (2016). Oznaczenia regionów anatomicznych: A1 - pierwszorzędowa kora słuchowa (primary auditory cortex), ag zakręt katowy (ang. angular gyrus), cals - bruzda ostrogowa (ang. calcarine sulcus), cing - zakręt obręczy (ang. cingulate), cs - bruzda środkowa (ang. central sulcus), ifg - dolny zakręt czołowy (ang. inferior frontal gyrus), infs - dolna bruzda czołowa (ang. intermediate frontal sulcus), M1 - pierwszorzędowa kora ruchowa (ang. primary motor cortex), mfg - środkówy zakręt czołowy (ang. middle frontal gyrus), mtc - środkowa część płata skroniowego (ang. middle temporal cortex), phf - formacja hipokampalna (ang. parahippocampal formation), pmc - kora tylnoprzyśrodkowa (ang. posteromedial cortex), S1 - pierwszorzędowa kora czuciowa (ang. primary sensory cortex), tt - zakręt skroniowy przedni poprzeczny (ang. transverse temporal gyrus), V1 - pierwszorzędkowa kora wzrokowa (primary visual cortex), vmpfc - brzusznoprzyśrodkowa część kory przedczołowej (ventromedial prefrontal cortex); sieci w podziale Yeo i współaut. (2011) na siedem części: DAN - grzbietowa sieć uwagowa, DMN - sieć aktywności spoczynkowej, FPN - sieć czołowo-ciemieniowa, LIM - sieć limbiczna, SMT - sieć czuciowo-ruchowa, VAN - brzuszna sieć uwagowa.

Próby wyjaśnienia dynamiki (a zarazem funkcji) wolnych oscylacji odbywaja się obecnie głównie poprzez tworzenie modeli matematycznych aktywności neuronalnej (DECo i współaut. 2013). Jedno $z$ najpopularniejszych wyjaśnień mechanizmu wolnych fluktuacji spoczynkowych zakłada, że sa one skutkiem utrzymywania się sieci blisko progu wzbudzenia, który to stan zapewnia optymalna dynamikę reakcji wewnattrz sieci. Bardziej skromne wyjaśnienia mówią o tym, że wolne fluktuacje to prosty mechanizm impulsów „odświeżających” połączenia nerwowe, służący podtrzymywaniu aktywności neuronów i połączeń synaptycznych przy życiu. Zwiazki neuronalnych i pozaneuronalnych źródeł oscylacji $z$ pewnościa wymagaja jeszcze dalszego badania.

ronalne źródła wolnych fluktuacji można znaleźć w publikacjach Drew (2018) oraz Lu i współaut. (2019).

\section{ORGANIZACJA MÓZGOWA SIECI FUNKCJONALNYCH}

Rozkład przestrzenny poszczególnych elementów omawianych sieci sprawia raczej chaotyczne wrażenie. Dlaczego niektóre zespoły funkcjonalne, rozproszone po różnych płatach mózgu, tworzą tzw. sieci rozległe (lub inaczej długozasięgowe, ang. large-scale networks)? Mogłoby się wydawać, że największa synchronizacja aktywności powinna zachodzić w przyległych do siebie obszarach kory (jak w przypadku zintegrowanej funkcjonalnie i przestrzennie kory wzorkowej). Pytanie o przestrzenne zwiazki między sieciami wydaje się kluczowe w próbie zrozumienia ram organizacji funkcjonalnej mózgu.

Zasada, która porzadkuje ukształtowanie kory i zależna od niej organizację sieci, została odkryta w badaniach MARGULIESA i współaut. (2016). Badacze ci skoncentrowali 
się na wyróżnieniu w aktywności spoczynkowej mózgu (metodą analiz czynnikowych) pewnych jej ogólnych wymiarów.

Tego rodzaju wymiary organizacji połaczeń były od lat używane w opisie funkcjonalnym niektórych części mózgu: przykładem może być obserwowana w obszarach wzrokowych systematyczna organizacja gradientów odległości radialnej i horyzontalnej od środka pola widzenia, które łącznie opisują organizacje pierwszorzędowej kory wzrokowej (tzw. retinotopię). Dostrzeżenie pewnego kontinuum funkcjonalnego jest również podstawą do wyróżnienia większych systemów organizacji mózgowej, np. drogi brzusznej przetwarzania informacji wzrokowej. Prowadzi ona od pierwszorzędowej kory wzrokowej, analizujacej proste cechy fizyczne bodźców, przez podstawne rejony kory skroniowej, przetwarzajace bardziej złożone cechy obiektów, po środkową i przednia część płata skroniowego, gdzie analizowane sa reprezentacje semantyczne (niezależne od poszczególnych modalności zmysłowych).

W badaniu gradientów obejmujących cała powierzchnię kory mózgu, MARGULIESOWI i współaut. (2016) pomogła nowa metoda redukcji wymiarów sygnału, niskorzędowe osadzenie dyfuzji (ang. diffusion embedding), która okazała się bardziej efektywna niż wcześniej stosowane metody przekształceń liniowych. Okazało się, że główny wymiar, według którego można uporządkować wszystkie obszary kory mózgu, prowadzi od pól pierwszorzędowych (kory wzrokowej, czuciowo-ruchowej i słuchowej) na jednym końcu skali, do regionów kory nieprzetwarzajacych informacji zmysłowej (takich jak zakręt katowy, dziobowa część zakrętu obręczy, kora tylnoprzyśrodkowa, środkowy zakręt skroniowy oraz środkowy i górny zakręt czołowy) na drugim jej końcu (Ryc. 2A). Ten pierwszy gradient, wyjaśniajacy największą część zmienności sygnału, można określić jako gradient „zmysłowo-asocjacyjny". Obszary, cechujace się jego najwyższymi wartościami po stronie „asocjacyjnej”, to po prostu obszary sieci DMN. Drugi w kolejności gradient, który nakładał się na pierwszy, różnicuje głównie obszary pierwszorzędowe, prowadzac od kory wzorkowej na jednym końcu skali, do kory czuciowo-ruchowej i słuchowej na drugim ${ }^{9}$. Można więc podsumować go jako gradient „percepcyjno-ruchowy".

\footnotetext{
${ }^{9}$ Kora czuciowo-ruchowa i słuchowa bardzo często grupuja się w jedna, nadrzędna sieć funkcjonalną. Wynika to prawdopodobnie $z$ faktu, że ośrodki ruchowe twarzy, zaangażowane w wytwarzanie mowy, są blisko funkcjonalnie zwiazane zarówno $\mathrm{z}$ pozostałymi ośrodkami czuciowo-ruchowymi, jak i z modalnością słuchową.
}

Ujawnienie nadrzędnych wymiarów organizacji kory w oparciu o dane funkcjonalne pozwoliło na dalszy krok: próbę powiązania tej organizacji $z$ anatomia kory mózgu. Miejsca o maksymalnej wartości gradientu pierwszego (punkty najbardziej „asocjacyjne”, wewnątrz odrębnych przestrzennie częśsi DMN) uznano za centra, względem których wyliczono odległość wszystkich pozostałych punktów na powierzchni kory mózgu (Ryc. 2B). Zastosowano przy tym miare minimalnej odległości geodezyjnej, czyli takiej, która uwzględnia pofałdowanie kory mózgu (odległość geodezyjna jest to dystans, który trzeba pokonać by przemieścić się między dwoma punktami po danej powierzchni). Okazało się, że centra DMN sa maksymalnie i równomiernie oddalone od bruzd ostrogowej i centralnej, które stanowią anatomiczne wyznaczniki (odpowiednio) kory wzrokowej i czuciowo-ruchowej. Odległość geodezyjna obszarów rosła więc wraz $z$ ich odległością na skali pierwszego gradientu ${ }^{10}$.

Zasada, wedle której obszary DMN sa zawsze możliwie maksymalnie oddalone od obszarów zmysłowych pozwala zrozumieć wzorzec przestrzenny ułożenia sieci (Ryc. 2C-E). Aby zauważyć regularny wzorzec uporzadkowania, należy przyjrzeć się fragmentom kory wyznaczonym $z$ jednej strony przez obszar należący do DMN, a $z$ drugiej, przez obszar pierwszorzędowy. Na takich odcinkach sieci układaja się w poprzeczne pasy w kolejności 1-4: (1) DMN, (2) FPN, (3a) $\operatorname{VAN}(\mathrm{CON})$ lub (3b) DAN, (4a) SMN lub (4b) VIS. Rozwidlenia przestrzenne na dalszych etapach uporządkowania wynikają $z$ "rozchodzenia się" gradientu pierwszego względem gradientu drugiego.

Fakt, że obszary sieci sa odseparowane jednocześnie fizycznie i funkcjonalnie pozwala przyjąć ogólna hipotezę dotyczaca organizacji kory mózgu. Pojawia się ona w literaturze pod nazwa hipotezy o „uwiazaniu" (funkcji do struktury; ang. tethering hypothesis): kora asocjacyjna może pełnić swoja funkcje, tj. integrować informacje pochodzace $z$ różnych modalności, dzięki swojemu fizycznemu oddaleniu od kory zmysłowej (BuCKNER i KRIENEN 2013). Kora mózgu człowieka jest nie tylko znacznie większa niż $\mathrm{u}$ innych naczelnych, ale też obszary asocja-

\footnotetext{
${ }^{10}$ Wartość gradientu zmienia się szczególnie szybko w odległości 2,5-4 cm od punktu maksymalnego (w DMN), po czym osiaga plateau rozciagające się aż do ok. $6 \mathrm{~cm}$ od tego punktu (Ryc. 2C). Zależność ta jest więc nieliniowa, choć da się ja również opisać liniowo na poziomie $r=0,74$. Szybka zmiana wartości gradientu w odległościach pośrednich może leżeć u podłoża grupowania się sieci w dwa nadrzędne systemy (system „wewnętrzny” w obszarach o wysokich i szybko spadających wartościach gradientu i system „zewnętrzny" w obszarach o niskich wartościach gradientu; Ryc. 2D).
} 
cyjne zajmuja w niej nieproporcjonalnie dużo miejsca. W niskorzędowych obszarach kory zmysłowej i ruchowej dominuje przetwarzanie szeregowe, dobrze uporzadkowane i hierarchiczne. Podejrzewa się, że szybkie zwiększenie objętości mózgu, które miało miejsce w ewolucji człowiekowatych, doprowadziło do uwolnienia dużych części kory od ograniczeń strukturalnych i kaskad aktywności tworzacych hierarchie przetwarzania zmysłowego. W „uwolnionej” przestrzeni zachodza procesy przetwarzania równoległego. Obszary te spajaja pozostałe części kory charakteryzujace się ścisła hierarchią strukturalna licznymi, luźniej uporządkowanymi połączeniami, które maja większy zasięg w przestrzeni mózgu i kształtuja się później w toku dojrzewania organizmu. Obserwacje, że DMN leży u podłoża procesów, które są w najmniejszym stopniu zwiazane sa $z$ przychodzacymi bodźcami (procesy planowania, wspominania, itp.) zgadzaja się $z$ nadrzędnym miejscem tej sieci w odkrytej hierarchii. Funkcje drugiej w hierarchii sieci FPN (manipulowanie informacjami pochodzenia wewnętrznego i zewnętrznego, tzw. pamięć robocza) również wymagaja izolowania od nadchodzacej informacji zmysłowej.

Najnowsze badania porównujace połączenia funkcjonalne i strukturalne (wyznaczone $\mathrm{w}$ obrazowaniu rezonansem magnetycznym zależnym od dyfuzji ang. diffusion spectrum imaging, DSI) potwierdziły, że związek mię$\mathrm{dzy}$ nimi nie jest jednorodny w różnych częściach mózgu (VÁzQUEZ-RoDRÍGUEZ i współaut. 2019). Organizacja strukturalna znacznie lepiej przewiduje zwiazki funkcjonalne między obszarami w pierwszorzędowej korze zmysłowej i ruchowej, niż w korze asocjacyjnej, zgodnie $z$ funkcjonalnymi hierarchiami. Przy pomocy podobnych, makroskopowych gradientów można opisać cytoarchitektonikę kory (FULCHER i współaut. 2019), jak również stopień mielinizacji, zróżnicowanie warstw kory i jej zmienna grubość (WAGSTYL i współaut. 2015, HUNTENBURG i współaut. 2017) oraz ekspresję genów (zwiąanych $Z$ cytoarchitektonika i fizjologia synaps) (BURT i współaut. 2018). Uwzględnienie makroskopowych gradientów znacznie poprawia efektywność stosowanych modeli biofizycznych, reprezentujacych dynamikę mózgowych obwodów neuronalnych (DEMIRTAŞ i współaut. 2019).

\section{OPISYWANIE AKTYWNOŚCI MÓZGU W KATEGORIACH SIECI}

Metody analizy grupujące aktywność różnych obszarów mózgu przyczyniły się do podziału mózgu na sieci spoczynkowe (Ryc. 1B) (POWER i współaut. 2011) i rozwoju ba- dań funkcjonalnych mózgu, ale równocześnie okazały się przydatne w badaniu procesów kognitywnych, a także dysfunkcji poznawczych i chorób. Szczegółowy przegląd wyników opartych o analizy dotyczace sieci w odniesieniu do różnych badanych populacji wykracza poza możliwości i cele niniejszego szkicu. Zaznaczę więc tylko najważniejsze obszary, w których nowe i tradycyjne metody analizy sieci znajduja intensywne zastosowanie.

Wyodrębnienie sieci funkcjonalnych znajduje zastosowanie np. w badaniach dotyczacych cech osobowości (BEATY i współaut. 2015, KONG i współaut. 2018) czy inteligencji (DuBoIs i współaut. 2018). Pokazano np. że lepszym możliwościom poznawczym sprzyja obecność wysokiej segregacji obszarów funkcjonalnych w stanie spoczynku i niskiej segregacji przy wykonywaniu wymagajacych zadań umysłowych. Kluczowe znaczenie w adaptowaniu się do nowych zadań odgrywa sieć czołowo-ciemieniowa i jej stopień skomunikowania $z$ pozostałymi sieciami (Cole i współaut. 2013).

Poznawanie własności sieci pozwala również na opisywanie procesów towarzyszacych rozwojowi i starzeniu się organizmu. Wykazano np. że wraz $z$ wiekiem segregacja pomiędzy różnymi sieciami funkcjonalnymi zmniejsza się (są one bardziej jednorodnie powiazane między soba). Mniejsza specjalizacja charakteryzuje również rozwijające się mózgi dzieci, choć mechanizmy stojące za mniejszą segregacją obszarów funkcjonalnych u osób starszych i dzieci są różne (WiG 2017). Młody mózg kształtowany jest przez czynniki środowiskowe i podlega uczeniu (specjalizacji) w oparciu o doświadczenie. Uczenie zachodzi również w późniejszym okresie życia, jednak towarzysza mu wtedy zmiany neurodegeneracyjne. Mniejsza segregacja obszarów funkcjonalnych w starzejącym się mózgu może wiązać się $z$ mechanizmami kompensacyjnymi, pozwalajacymi na zachowanie ważnych funkcji poznawczych mimo kumulujących się uszkodzeń.

Badanie aktywności spoczynkowej mózgu pokazało, że wzorce sieci funkcjonalnych ujawniaja zmiany zwiazane $z$ zaburzeniami psychicznymi. Porównanie charakterystycznych własności sieci funkcjonalnych dostarczyło nowych informacji o mózgowych korelatach schizofrenii, choroby Alzheimera, ADHD, autyzmu, zaburzeń afektywnych, chorób powodujących dysfunkcje ruchowe i wielu innych. Warto tu odnotować ogólny wniosek uzyskany w metaanalizie kilkudziesięciu różnych chorób: obserwowane w nich uszkodzenia dotykaja najczęściej centralnych węzłów sieci (ang. hubs), charakteryzujących się największą liczbą połączeń 
(CROssley i współaut. 2014). Efekt ten jest najbardziej widoczny w chorobie Alzheimera i schizofrenii, które stanowia przykłady najcięższych zaburzeń psychicznych (choć dotyczył innych węzłów w przypadku obu tych dysfunkcji). Poznanie sieci funkcjonalnych i możliwość ich wyodrębnienia w sygnale spoczynkowym ma potencjalnie duże znaczenie w zastosowaniach klinicznych ze względu na łatwość badania stanu spoczynkowego. Analizy oparte o spontaniczna aktywność mózgu umożliwiają badanie pacjentów niezdolnych do wzięcia udziału w rozwiazywaniu bardziej skomplikowanych zadań (ze względu na deficyty uwagi, ograniczenia ruchowe czy zaburzenia świadomości). Ważnym osiagnięciem, wyrosłym $z$ badania sieci funkcjonalnych, jest użycie spersonalizowanych modeli sieci do szacowania wyników interwencji chirurgicznej u osób $z$ epilepsja. Osiągnęły one wysoka trafność w przewidywaniu ognisk padaczkowych (SINHA i współaut. 2017, BANSAL i współaut. 2018).

\section{PODSUMOWANIE}

Badania aktywności spoczynkowej mózgu doprowadziły do odkrycia jego „funkcjonalnego szkieletu", sieci połączeń wewnętrznych, leżących u podłoża aktywności poznawczej człowieka. Ostatnie lata przyniosły wyjatkowy postęp w mapowaniu architektury funkcjonalnej mózgu i znaczaco poszerzyły wiedzę o organizacji i roli poszczególnych sieci w kształtowaniu się możliwości poznawczych człowieka. Mimo że wiele pytań dotyczacych wolnych fluktuacji spoczynkowych i ich neuronalnego podłoża oczekuje jeszcze na wyjaśnienie, dotychczasowe badania tworza spójny obraz jednostek funkcjonalnych wyodrębnianych na podstawie sygnału BOLD, uporządkowanych w sposób hierarchiczny w nadrzędne systemy, odpowiedzialne za „niższe” i „wyższe” funkcje poznawcze. Wiele wskazuje na to, że przyszłe badania dotyczące organizacji funkcjonalnej mózgu będa zogniskowane na interakcjach między sieciami i modelach ujmujących jej całościowa dynamikę (BASSETT i SPORNS 2017).

$$
\text { Streszczenie }
$$

Funkcjonalne obrazowanie rezonansem magnetycznym ujawniło wolne, spontaniczne fluktuacje sygnału BOLD, odzwierciedlające zsynchronizowana aktywność różnych, często odległych obszarów mózgu. Na podstawie tych fluktuacji wyróżnione zostały tzw. sieci spoczynkowe (lub inaczej, sieci funkcjonalne), których wewnętrzna aktywność cechuje się wysoką spójnością niezależnie od tego, czy mierzy się ją w stanie spoczynku czy w trakcie zadań poznawczych lub behawioralnych. Niniejsza praca omawia najważniejsze sieci funkcjonalne wyróżniane w badaniach neuroobrazowych wraz $z$ metodami służącymi do ich identyfikacji, neuronalne podłoże spontanicznych fluktuacji oraz ogólne zasady organizacji sieci w korze mózgu. Przedstawiono również, jak wyodrębnienie systemów funkcjonalnych mózgu wpłynęło na opis procesów poznawczych w normie i w patologii.

\section{LITERATURA}

ANDREWS-HANNA J. R., REIDLER J. S., SEPUlCRE J., POUlin R., BuckNeR R. L., 2010. Functional-anatomic fractionation of the brain's default network. Neuron 65, 550-562.

BANSAL K., NAKUCI J., MuldoON S. F., 2018. Personalized brain network models for assessing structure-function relationships. Curr. Opin. Neurobiol. 52, 42-47.

BAssETT D. S., SPORNS O., 2017. Network neuroscience. Nat. Neurosci. 20, 353-364.

Beaty R. E., KaUfMaN S. B., BEnEDEK M., JunG R. E., KenetT Y. N., JaUK E., Neubauer A. C., SilviA P. J., 2015. Personality and complex brain networks: The role of openness to experience in default network efficiency. Hum. Brain Mapp. 37, 773-779.

Beckmann C. F., DEluCA M., Devlin J. T., SMith S. M., 2005. Investigations into resting-state connectivity using independent component analysis. Philos. Trans. R. Soc. B Biol. Sci. 360, 1001-1013.

Bisley J. W., GOLDBERG M. E., 2010. Attention, intention, and priority in the parietal lobe. Annu. Rev. Neurosci. 33, 1-21.

BISWAL B., 2012. Resting state fMRI: A personal history. Neuroimage. 62, 938-44.

Biswal B., Yetkin F. Z., Haughton V. M., Hyde J. S., 1995. Functional connectivity in the motor cortex of resting human brain using echo- planar mri. Magn. Reson. Med. 34, 537-541.

Biswal B., Hudetz A. G., Yetkin F. Z., HaughTON V. M., HYDE J. S., 1997. Hypercapnia reversibly suppresses low-frequency fluctuations in the human motor cortex during rest using echo-planar MRI. J. Cereb. Blood Flow Metab. 17, 301-308.

BuCKNER R. L., KRIENEN F. M., 2013. The evolution of distributed association networks in the human brain. Trends Cogn. Sci. 17, 648-65.

Burns S. P., Xing D., Shapley R. M., 2010. Comparisons of the dynamics of local field potential and multiunit activity signals in macaque visual cortex. J. Neurosci. 30, 13739-13749.

BurT J. B., DEMIRTAŞ M., ECKNER W. J., NAVEJAR N. M., Ji J. L., MARTIN W. J., BERNACCHIA A., ANTICEVIC A., MURRAY J. D., 2018. Hierarchy of transcriptomic specialization across human cortex captured by structural neuroimaging topography. Nat. Neurosci. 21, 1251-1259.

COLE M. W., SCHNEIDER W., 2007. The cognitive control network: Integrated cortical regions with dissociable functions. Neuroimage 37, 343-360.

Cole M. W., Reynolds J. R., POWer J. D., RePOVS G., ANTICEVIC A., BRAVER T. S., 2013. Multi-task connectivity reveals flexible hubs for adaptive task control. Nat. Neurosci. 16, 1348-1355.

Cole M. W., Bassett D. S., Power J. D., BRAVER T. S., PETERSEN S. E., 2014. Intrinsic and task-evoked network architectures of the human brain. Neuron 83, 238-251.

CorbetTA M., SHulman G. L., 2002. Control of goal-directed and stimulus-driven attention in the brain. Nat. Rev. Neurosci. 3, 201-215.

Corbetta M., PATEl G., Shulman G. L., 2008. The reorienting system of the human brain: 
from environment to theory of mind. Neuron $58,306-324$.

Cordes D., Haughton V. M., ARFanakis K., WendT G. J., TURski P. A., Moritz C. H., QUIGLEY M. A., MEYERAND M. E., 2000. Mapping functionally related regions of brain with functional connectivity MR imaging. Am. J. Neuroradiol. 21, 1636-1644.

Crossley N. A., Mechelli A., Scott J., CARletti F., FoX P. T., McGuire P., Bullmore E. T., 2014. The hubs of the human connectome are generally implicated in the anatomy of brain disorders. Brain 137, 2382-2395.

Deco G., JiRsa V. K., McinTOSH A. R., 2013. Resting brains never rest: Computational insights into potential cognitive architectures. Trends Neurosci. 36, 268-274.

DEMirTAS M., BURT J.B., HElmer M., Ji J.L., ADKINSON B. D., GLASSER M. F., VAN ESSEN D. C., Sotiropoulos S. N., ANTICEviC A., MurRay J. D., 2019. Hierarchical heterogeneity across human cortex shapes large-scale neural dynamics. Neuron 101, 1181-1194.e13.

DiXon M. L., ANDREWS-HANNA J. R., SPRENG R. N., IRving Z. C., Mills C., GIRN M., CHRISTOFF K., 2017. Interactions between the default network and dorsal attention network vary across default subsystems, time, and cognitive states. Neuroimage 147, 632-649.

DiXon M. L., De La Vega A., Mills C., AndRews-HANNA J., SPRENG R. N., COLE M. W., CHRISTOFF K., 2018. Heterogeneity within the frontoparietal control network and its relationship to the default and dorsal attention networks. Proc. Natl. Acad. Sci. USA 115, E1598-E1607.

Dosenbach N. U. F., Visscher K. M., PAlmeR E. D., Miezin F. M., Wenger K. K., Kang H. C., BuRgund E. D., GRIMES A. L., SchlagGar B. L., Petersen S. E., 2006. A core system for the implementation of task sets. Neuron 50, 799-812.

Doucet G., Naveau M., Petit L., Delcroix N., Zago L., CRIVEllo F., JOBARD G., TZOURIO-Mazoyer N., Mazoyer B., Mellet E., Joliot M., 2011. Brain activity at rest: A multiscale hierarchical functional organization. J. Neurophysiol. 105, 2753-2763.

DREW P. J., 2019. Vascular and neural basis of the BOLD signal. Curr. Opin. Neurobiol. 58, 61-69.

Dubois J., Galdi P., PaUl L. K., AdolphS R., 2018. A distributed brain network predicts general intelligence from resting-state human neuroimaging data. Philos. Trans. R. Soc. B Biol. Sci. 373, 20170284.

DUNCAN J., OWEN A. M., 2000. Common regions of the human frontal lobe recruited by diverse cognitive demands. Trends Neurosci. 23, 475483.

Egli T., Coynel D., Spalek K., Fastenrath M., FreytaG V., Heck A., LoOs E., Auschra B., PAPASSOTIROPOULOS A., DE QUERVAIN D. J.F., MilNiK A., 2018. Identification of two distinct working memory-related brain networks in healthy young adults. eNeuro 5, ENEURO.0222-17.2018.

Esterman M., NoOnan S.K., RosenberG M., DEGUTIS J., 2013. In the zone or zoning out? Tracking behavioral and neural fluctuations during sustained attention. Cereb. Cortex 23, 2712-2723.

Fox M. D., Snyder A. Z., Vincent J. L., CorbetTA M., VAN ESSEN D. C., RAICHLE M. E., 2005. The human brain is intrinsically organized into dynamic, anticorrelated functional networks. Proc. Natl. Acad. Sci. USA 102, 9673-9678.

Fox M. D., CoRBETTA M., SNYDER A. Z., VincEnT J. L., RAICHLE M. E., 2006. Spontaneous neuronal activity distinguishes human dorsal and ventral attention systems. Proc. Natl. Acad. Sci. USA 103, 10046-10051.

Fulcher B. D., Murray J. D., Zerbi V., WANG X. J., 2019. Multimodal gradients across mouse cortex. Proc. Natl. Acad. Sci. USA 116, 46894695.

Gelbard-Sagiv H., Mukamel R., Harel M., Mal$\mathrm{ACH}$ R., FRIED I., 2008. Internally generated reactivation of single neurons in human hippocampus during free recall. Science 322, 96101.

GENG J. J., Vossel S., 2013. Re-evaluating the role of TPJ in attentional control: Contextual updating? Neurosci. Biobehav. Rev. 37, 26082620.

Gratton C., Laumann T. O., Nielsen A. N., GREENE D. J., GORDON E. M., GILMORE A. W., NELSON S. M., COALSON R. S., SNYDER A. Z., Schlaggar B. L., Dosenbach N. U. F., PeTERSEN S. E., 2018. Functional brain networks are dominated by stable group and individual factors, not cognitive or daily variation. Neuron $98,439-452 . \mathrm{e} 5$.

Greicius M. D., Krasnow B., Reiss A. L., Menon V., 2003. Functional connectivity in the resting brain: A network analysis of the default mode hypothesis. Proc. Natl. Acad. Sci. USA 100, 253-258.

Hacker C. D., Snyder A. Z., Pahwa M., Corbetta M., LEUTHARDT E. C., 2017. Frequency-specific electrophysiologic correlates of resting state fMRI networks. Neuroimage 149, 446-457.

HunTENBURG J. M., BAZIN P.-L., GOUlas A., TARDIF C. L., VILLRINGER A., MARGUlies D. S., 2017. A systematic relationship between functional connectivity and intracortical myelin in the human cerebral cortex. Cereb. Cortex 27, 981-997.

IGELSTRÖM K. M., GRAZIANO M. S. A., 2017. The inferior parietal lobule and temporoparietal junction: A network perspective. Neuropsychologia $105,70-83$.

JUREWICZ K., 2019. Rola styku skroniowo-ciemieniowego $w$ aktualizacji przedmiotu uwagi. Praca doktorska. Instytut Biologii Doświadczalnej im. M. Nenckiego PAN.

Kandel E. R., Schwartz J.K., Jessell T. M., SieGELBAum S. A., HudsPeTH A. J. 2013. Principles of Neural Science, Fifth Edition. McGrawHill Education.

KaWAgOe T., OnODA K., Yamaguchi S., 2018. Different pre-scanning instructions induce distinct psychological and resting brain states during functional magnetic resonance imaging. Eur. J. Neurosci. 47, 77-82.

KEITEL A., GROSS J., 2016. Individual human brain areas can be identified from their characteristic spectral activation fingerprints. PLoS Biol. 14, e1002498.

Komorowski M. K., Aghabeig M., Nikadon J., PIOTROWSKI T., DRESZER J., BAEAJ B., LEWANDOWSKA M., WOJCIECHOWSKI J., PAWLACZYK N., SZMYTKE M., CicHOCKI A., DUCH W., 2018. Multi-level explanations in neuroscience II: EEG spectral fingerprints and tensor decompositions for understanding brain activity - Initial results. Acta Phys. Pol. B 49, 2011-2028.

Kong R., Li J., Orban C., Sabuncu M. R., LiU H., SCHAEFER A., SUN N., ZUO X.-N., HOLMES A. J., EICKHOFF S. B., YEO B. T. T., 2018. Spatial topography of individual-specific cortical 
networks predicts human cognition, personality, and emotion. Cereb. Cortex. 29, 25332551.

KRIENEN F. M., YEO B. T., BUCKNER R. L., 2014 Reconfigurable task-dependent functional coupling modes cluster around a core functional architecture. Philos. Trans. R. Soc. B Biol. Sci. 369, 20130526.

Kroger J. K., SABB F. W., Fales C. L., BOOKHEIMER S. Y., COHEN M. S., HOLYOAK K. J., 2002. Recruitment of anterior dorsolateral prefrontal cortex in human reasoning: a parametric study of relational complexity. Cereb. Cortex 12, 477-485.

KuCYI A., Schrouff J., Bickel S., Foster B. L., SHINE J. M., PARVIZI J., 2018. Intracranial electrophysiology reveals reproducible intrinsic functional connectivity within human brain networks. J. Neurosci. 38, 4230-4242.

LACHERT P., ZYGIEREWICZ J., JANUSEK D., PULAWSKI P., SAwOSZ P., KacPRZAK M., LIEBERT A., BLINOWSKA K. J., 2019. Causal coupling between electrophysiological signals, cerebral hemodynamics and systemic blood supply oscillations in mayer wave frequency range. Int. J. Neural Syst. 29.

Logothetis N. K., Pauls J., Augath M., Trinath T., OeltermanN A., 2001. Neurophysiological investigation of the basis of the fMRI signal. Nature 412, 150-157.

LOwE M. J., MOCK B. J., SORENSON J. A., 1998. Functional connectivity in single and multislice echoplanar imaging using resting-state fluctuations. Neuroimage 7, 119-132.

LU H., JAIME S., YANG Y., 2019. Origins of the resting-state functional MRI signal: Potential limitations of the "neurocentric" model. Front. Neurosci. 13, 1136.

MA Y., SHAIK M. A., KozBerg M. G., KIM S. H. PorTes J. P., Timerman D., Hillman E. M. C., 2016. Resting-state hemodynamics are spatiotemporally coupled to synchronized and symmetric neural activity in excitatory neu rons. Proc. Natl. Acad. Sci. USA 113, E8463-E8471.

Macaluso E., DoRICCHI F., 2013. Attention and predictions: control of spatial attention beyond the endogenous-exogenous dichotomy. Front. Hum. Neurosci. 7, 685.

MANTINI D., PERRUCCI M. G., DEL GRATTA C., ROMANI G. L., CORBETTA M., 2007. Electrophysiological signatures of resting state networks in the human brain. Proc. Natl. Acad. Sci. USA 104, 13170-13175.

Margulies D. S., Ghosh S. S., Goulas A., FalKIEWICZ M., HunTEnBURG J. M., LANGS G., BezGin G., EICKHOFF S. B., Castellanos F. X., Petrides M., JefFeries E., SMallwood J., 2016. Situating the default-mode network along a principal gradient of macroscale cortical organization. Proc. Natl. Acad. Sci. USA 113, 12574-12579.

Mateo C., KNUTSEN P. M., Tsai P. S., ShiH A. Y., KLEINFELD D., 2017. Entrainment of arteriole vasomotor fluctuations by neural activity is a basis of blood-oxygenation-level-dependent "resting-state" connectivity. Neuron 96, 936-948. e3.

Mazoyer B., Zago L., MEllet E., Bricogne S., ETARd O., Houdé O., Crivello F., Joliot M. Petit L., TZOuRIO-Mazoyer N., 2001. Cortical networks for working memory and executive functions sustain the conscious resting state in man. Brain Res. Bull. 54, 287-298.

OgaWA S., LeE T. M., KAY A. R., TANK D. W., 1990. Brain magnetic resonance imaging with contrast dependent on blood oxygenation. Proc. Natl. Acad. Sci. USA 87, 9868-9872.

Patriat R., Molloy E. K., MeIER T. B., KirK G. R., NAIR V. A., MEYERAND M. E., PRABHAKARAN V., BIRN R. M., 2013. The effect of resting condition on resting-state fMRI reliability and consistency: A comparison between resting with eyes open, closed, and fixated. Neuroimage 78, 463-73.

Power J. D., COHen A. L., Nelson S. M., Wig G. S., Barnes K. A., Church J. A., Vogel A. C., LAUMANN T. O., MIEZIN F. M., SCHLAGGAR B. L., Petersen S. E., 2011. Functional network organization of the human brain. Neuron 72, 665-678.

Raichle M. E., Macleod A. M., Snyder A. Z., PoWERS W. J., GuSNARD D. A., SHUlman G. L., 2001. A default mode of brain function. Proc. Natl. Acad. Sci. USA 98, 676-682.

RUBINOV M., SPORNS O., 2010. Complex network measures of brain connectivity: Uses and interpretations. Neuroimage 52, 1059-1069.

SCHÖLVINCK M. L., MAIER A., YE F. Q., DUYN J. H., LEOPOLD D. A., 2010. Neural basis of global resting-state fMRI activity. Proc. Natl. Acad. Sci. USA 107, 10238-10243.

Seeley W. W., Menon V., Schatzberg A. F., KelLER J., GLOVer G. H., KenNA H., REISS A. L., GREICIUS M. D., 2007. Dissociable Intrinsic Connectivity Networks for Salience Processing and Executive Control. J. Neurosci. 27, 23492356.

ShMUEL A., LEOPOLD D. A., 2008. Neuronal correlates of spontaneous fluctuations in fMRI signals in monkey visual cortex: Implications for functional connectivity at rest. Hum. Brain Mapp. 29, 751-761.

Shulman G. L., Fiez J. A., CORBEtTA M., BuCKNer R. L., Miezin F. M., RAichle M. E., PeterSEN S. E., 1997. Common blood flow changes across visual tasks. II. Decreases in cerebral cortex. J. Cogn. Neurosci. 9, 648-663.

Sinha N., DaUWEls J., KaISer M., CASH S. S., Westover M. B., WANG Y., TAYLOR P. N., 2017. Predicting neurosurgical outcomes in focal epilepsy patients using computational modelling. Brain 140, 319-332.

SMith S. M., FOX P. T., Miller K. L., GlahN D. C., FOX P. M., MACKAY C. E., FILIPPINI N., WATKINS K. E., TORO R., LAIRD A. R., BECKMANN C. F., 2009. Correspondence of the brain's functional architecture during activation and rest. Proc. Natl. Acad. Sci. USA 106, 13040-13045

Spreng R. N., Stevens W. D., Chamberlain J. P., GILMORE A. W., Schacter D. L., 2010. Default network activity, coupled with the frontoparietal control network, supports goal-directed cognition. Neuroimage 53, 303-317.

Tong Y., Frederick B. DeB., 2010. Time lag dependent multimodal processing of concurrent fMRI and near-infrared spectroscopy (NIRS) data suggests a global circulatory origin for low-frequency oscillation signals in human brain. Neuroimage 53, 553-564.

TONG Y., HOCKE L. M., FAN X., JANES A. C., FREDERICK B. DEB., 2015. Can apparent resting state connectivity arise from systemic fluctuations? Front. Hum. Neurosci. 9, 285.

TONG Y., YAO J. F., CHEN J. J., FREDERICK B. D., 2019. The resting-state fMRI arterial signal predicts differential blood transit time through the brain. J. Cereb. Blood Flow Metab. 39, 1148-1160.

VÁZQueZ-Rodríguez B., SuÁrez L. E., MARKello R. D., Shafiei G., Paquola C., Hagmann P., 
VAn Den Heuvel M. P., Bernhardt B. C., SPRENG R. N., MISIC B., 2019. Gradients of structure-function tethering across neocortex. Proc. Natl. Acad. Sci. USA 116, 21219-21227.

Vincent J. L., KahN I., SNyDeR A. Z., RAICHLE M. E., BUCKNER R. L., 2008. Evidence for a frontoparietal control system revealed by intrinsic functional connectivity. J. Neurophysiol. 100, 3328-3342.

Wagstyl K., Ronan L., GoodyeR I. M., FletcheR P. C., 2015. Cortical thickness gradients in structural hierarchies. Neuroimage 111, 241250.

WEISSMAN D. H., RoBERTS K. C., Visscher K. M., WOLDORFF M. G., 2006. The neural bases of momentary lapses in attention. Nat. Neurosci. 9, 971-978.

WIG G. S., 2017. Segregated systems of human brain networks. Trends Cogn. Sci. 21, 981996.

Winder A. T., EchagarRuga C., ZHANG Q., DREW P. J., 2017. Weak correlations between hemodynamic signals and ongoing neural activity during the resting state. Nat. Neurosci. 20, 1761-1769.

YARKONI T., BARCH D. M., GRAY J. R., CONTURO T. E., BRAVER T. S., 2009. BOLD Correlates of trial-by-trial reaction time variability in gray and white matter: A multi-study fMRI analysis. PLoS One 4, e4257.

YARKONI T., POLDRACK R. A., NichOlS T. E., VAN ESSEN D. C., WAGER T. D., 2011. Large-scale automated synthesis of human functional neuroimaging data. Nat. Methods 8, 665-670.

Yeo B. T. T., KRIENEn F. M., Sepulcre J., SABunCU M. R., LASHKari D., HOllinshead M., ROFFMAN J. L., SMOller J. W., ZÖLlei L., POLIMENI J. R., FISCHL B., LIU H., BUCKNER R. L., 2011. The organization of the human cerebral cortex estimated by intrinsic functional connectivity. J. Neurophysiol. 106, 1125-1165.

KOSMOS Vol. 69, 1, 105-121, 2020

\section{KATARZYNA JUREWICZ}

Laboratory of Emotions Neurobiology, Nencki Institute of Experimental Biology PAS, 3Pasteur St., 02-093 Warszawa

RESTING STATE NETWORKS AND THEIR ROLE IN FUNCTIONAL ORGANISATION OF THE BRAIN

Summary

Functional magnetic resonance imaging revealed slow, spontaneous fluctuations of BOLD (blood-oxygenation level dependent) signal, which were synchronized between various distant brain areas. These patterns of synchronization were used to attribute brain regions into "resting state networks" known as "intrinsic connectivity networks", which exhibited highly correlated activity independently from current, on-going tasks. The present review describes the most important functional networks invoked in neuroimaging studies together with methods for their identification, evidence for their neuronal underpinnings and the principles of their cortical organization. Finally, I discuss how the discovery of brain functional systems impacts neuroscientific studies of cognitive functions in health and disease.

Key words: cortical organisation, fMRI, functional connectivity, functional networks, intrinsic connectivity networks 
